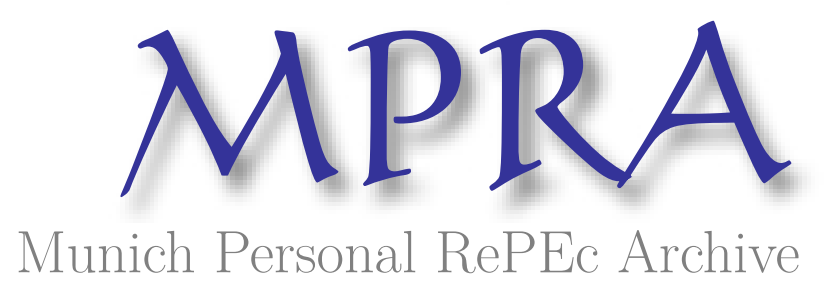

\title{
The nexus between underlying dynamics of bank capital buffer and performance.
}

Mamatzakis, Emmanuel and Bagntasarian, Anna

University of Sussex Business School

14 March 2019

Online at https://mpra.ub.uni-muenchen.de/92961/

MPRA Paper No. 92961, posted 01 Apr 2019 13:22 UTC 
The nexus between underlying dynamics of bank capital buffer and performance.

\title{
Mamatzakis E. ${ }^{\mathrm{a}}$ and Bagntasarian A. ${ }^{\mathrm{b}}$
}

March 2019

\begin{abstract}
This paper reveals the underlying dynamics between the capital buffer and bank performance in EU-27 countries. A dynamic panel analysis shows that capital buffer is significantly affected by bank performance and risk exposure. Remarkably, a threshold analysis identifies regime changes for the underlying relationships during the financial crisis of 2008. We find a positive relationship between the capital buffer and performance for banks that fall in the low performance regime, while a negative relationship is reported for the banks that belong to the high regime. Threshold results also show that buffer exerts a positive impact on bank performance. Although regulation reforms that aim to raise the capital requirements could improve bank performance and stability, these improvements are not homogeneous across banks.
\end{abstract}

Keywords: Capital buffer; Dynamic threshold; Performance; Bank default risk.

JEL classification: G20; G21; G28

\footnotetext{
${ }^{a}$ School of Business, Management and Economics, Jubilee Building, University of Sussex, Falmer, BN1 9SL, UK, e-mail: e.mamatzakis@ @ussex.ac.uk, ${ }^{b}$ Bank of England, Threadneedle St, London EC2R 8AH, UK, e-mail: Anna.Bagntasarian@bankofengland.co.uk.
} 


\section{Introduction}

The financial crisis of 2008 shows that sudden changes in asset quality and value can quickly diminish bank capital, leaving banks with inadequate capital to deal with unexpected losses. As a result, capital buffer requirements have become an instrument of providing a cushion during adverse economic conditions. In some respect, capital buffer is a macro-prudential tool that could prevent bank excessive risk-taking (Ayuso et al. 2004; Jokipii and Milne 2008, Mamatzakis and Koutsomanoli-Filippaki 2009; Mamatzakis and Psillaki, 2017). Under Basel III, banks need to maintain a mandatory capital buffer of 2.5 percent of common equity. In the case of violation of this minimum requirement, the Basel Committee would assert restrictions on dividends and remunerations. Furthermore, Basel Committee may also require a discretionary countercyclical buffer up to another 2.5 percent of capital during periods when funds are easy to borrow. The main aim of counter-cyclical buffer is to prevent market instability during periods of excessive credit growth by providing banks with extra capital (Krug et al. 2015). Banks also have an incentive to hold capital buffer in order to signal soundness and thereby, receive higher credit rating scores. In addition, banks may hold a capital buffer to avoid costs related to penalties and restrictions imposed by the regulators when the former violate minimum capital requirements (Buser et al. 1981; Jokipii and Milne 2011; Mamatzakis and Bermpei, 2016).

Finally, there is an extensive literature on examining the association between capital requirements and bank's asset structure (Alali and Jaggi 2011; Chu et al. 2007; Furfine 2001; Pasiouras et al. 2006; Repullo and Suarez 2012; Rime 2001; Shrieves and Dahl 1992; Mamatzakis and Koutsomanoli-Filippaki 2009; Mamatzakis and Psillaki, 2017). Since regulators imply restrictions on banks to limit their risk exposure, it could be the 
case that banks with a higher risk exposure might maintain a higher capital buffer (Baule 2014; Calomiris and Wilson 2004; Flannery and Rangan 2008; Jokipii and Milne 2008, 2011; Mamatzakis and Koutsomanoli-Filippaki 2009).

Despite the benefits of financial stability due to the adequate capital buffer, some literature argues that raising capital through capital markets is costly especially during economic downturns (Alfon et al. 2004; Ayuso et al. 2004; Berger and Bonaccorsi di Patti 2006). Banks might rely on their own profitability to build up a capital buffer (Shim 2013). To this day, there is not a clear consensus in the literature on the relationship between the capital buffer and bank performance. There are studies that provide evidence for a negative association between bank performance and capital buffer (Alfon et al. 2004; Ayuso et al. 2004; Berger and Bonaccorsi di Patti 2006; Jokipii and Milne 2008; Mamatzakis and Tsionas, 2019; Mamatzakis and Vu 2018; Mamatzakis and Tsionas, 2017) suggesting that strong bank performance substitutes for capital as a cushion against unexpected losses. Another strand of literature (Berger 1995, Flannery and Rangan, 2008; Nier and Bauman 2006; Shim 2013; Mamatzakis and Vu 2018; Mamatzakis and Tsionas, 2017) finds a positive relationship between performance and buffer indicating that an improvement in bank performance increases buffer.

Concerning the capital buffer and risk nexus, there are several empirical studies (Baule 2014; Calomiris and Wilson 2004; Flannery and Rangan 2008; Francis and Osborne 2012; Jokipii and Milne 2008; Shim 2013; Mamatzakis and Tsionas, 2019; Mamatzakis and $\mathrm{Vu}$ 2018; Mamatzakis and Tsionas, 2017) testing whether increasing the risk taken by banks force them to maintain a higher capital buffer. The results show that there is a 
positive relationship between bank risk-taking and capital buffer, indicating that banks with a greater risk exposure choose to hold a higher capital buffer. Following previous literature (Ayuso et al. 2004; Jokipii and Milne 2008), we employ non-performing loans, off-balance-sheet items and risk-weighted assets to account for bank risk exposure, while as a measure of bank default risk we include Altman's Z-Score (Altman 1968).

This paper contributes to the literature of the relationship between capital buffer, bank performance and risk in several ways. First of all, unlike previous studies, this paper employs a dynamic panel threshold analysis. Similarly, to the conventional dynamic panel analysis, threshold methodology accounts for the dynamic nature of capital buffer and for the potential endogeneity of the explanatory variables. The main advantage of the threshold analysis over dynamic panel regressions is that it allows data itself to define the crisis years. Thus, threshold analysis identifies the presence of regime switches in the relationship between the capital buffer and other bank-specific variables. Specifically, we investigate the presence of regime switches for the relationship between a) capital buffer and performance as measured by bank efficiency and b) capital buffer and risk of default as measured by Altman's Z-Score. Furthermore, we account for the inverse relationship between these variables. For this reason, we examine the impact of capital buffer on bank performance and Altman's Z-Score using buffer as a threshold variable. Additionally, we opt for different measures of performance and risk to reveal all potential determinants of bank capital buffer. Finally, this study covers a period (2004 - 2013) that includes the crisis years and therefore, we take into account any differences due to the financial meltdown in $2007-2008$ and the recovery thereafter. 
This study confirms prior research, suggesting that bank performance and risk have a strong impact on the capital buffer. However, this analysis shows that the impact of efficiency on buffer varies across banks. Estimated results demonstrate a strong positive impact of performance on the buffer for banks in the low performance regime, while for the relatively better performing banks a further improvement in performance would reduce capital buffer. Furthermore, we show that capital buffer would reduce bank risk of default. We also perform a sensitivity analysis to account for any potential endogeneity and therefore, underlying causality, opting for a flexible panel VAR model. This model provides the response of bank capital buffer to shocks in efficiency and risk of default in the VAR.

The paper is organised as follows. Section 2 sets the hypotheses to be tested in the empirical section. Section 3 presents our data, whilst section 4 discusses the methodology. Next, section 5 reports regression results and the subsequent threshold analysis. Section 6 develops our sensitivity analysis employing Panel-VAR methodology and finally, section 7 concludes.

2. Hypotheses development

\subsection{The dynamic adjustment hypothesis}

Following previous literature (Ayuso et al. 2004; Guidara et al. 2013; Jokipii and Milne 2008, 2011; Stolz and Wedow 2011), we hypothesise that banks might need time to adjust their capital buffer. In the absence of adjustment costs in capital ratio, banks would not hold capital in excess of the minimum regulatory requirement (Stolz and Wedow 2011). As banks would adjust the capital buffer with some time lags, the capital 
buffer of the previous period should have a positive and statistically significant impact on the current capital buffer.

H1. Adjustment in bank capital would affect positively the capital buffer.

\subsection{Bank performance hypothesis.}

Past research (Alfon 2004; Ayuso et al. 2004; Guidara et al. 2013; Jokipii and Milne 2008; Nier and Baumann 2006; Rime 2001; Shim 2013) provides mixed results regarding the relationship between bank capital buffer and performance. Alfon (2004), Ayuso et al. (2004), Guidara et al. (2013) and Jokipii and Milne (2008) find a negative relationship between capital and ROE. Berger (1995), Flannery and Rangan (2008), Nier and Baumann (2006), Rime (2001) and Shim (2013) provide evidence of a positive relationship between bank profitability and capital buffer, indicating that more profitable banks hold a higher capital buffer. This strand of literature is in line with the pecking order theory, according to which banks prefer retained earnings as their main source of financing since external sources can be costly (Myers and Majluf 1984).

In this study, beyond the accounting measures of bank performance such as return on equity (ROE), return on assets (ROA) and net interest margin (NIM), we also employ bank's cost efficiency derived from the Stochastic Frontier Analysis (SFA). Although, there have been several studies about the link between total regulatory capital and efficiency, up till now the literature on the relationship between the capital buffer and efficiency has been rather inconclusive. In an early study, Kwan and Eisenbeis (1997) using quarterly data over the period 1986 - 1995 for 352 U.S. bank holding companies, examine the relationships among bank risk-taking, capital and efficiency. The authors document a positive relationship between inefficiency and capital providing evidence 
of regulatory pressure over underperforming banks to maintain more capital. Moreover, the authors show that better capitalized banks exhibit a higher level of efficiency than less capitalized banks.

Berger and Bonaccorsi di Patti (2006) find a negative relationship between regulatory capital and efficiency for U.S. banks over the period 1990 - 1995. Their results support the "efficient-risk hypothesis" which suggests that more efficient institutions would hold relatively low capital, since higher expected returns from the greater efficiency may substitute capital.

In line with these results, Altunbas et al. (2007) using a sample of European banks for the period $1992-2000$, show that inefficient European banks tend to hold more capital and evolve in less risky activities. ${ }^{1}$ These results provide further support for the regulatory pressure over underperforming banks to maintain more capital. However, Altunbas et al. (2007) argue that this relationship varies with the level of bank efficiency and across ownership types.

Arguably, the opposite relationship might also exist supporting the "franchise-value hypothesis" (Berger and Bonaccorsi di Patti 2006). According to the "franchise-value hypothesis", more efficient institutions tend to maintain a relatively high capital to protect their franchise value and future income derived from high efficiency (Berger and Bonaccorsi di Patti 2006; Kwan and Eisenbeis 1997). This hypothesis could also be reinforced by the pecking order theory according to which banks will prefer to finance their capital needs internally, especially when the access to capital markets is difficult. Therefore, more efficient banks that are expected to be more profitable (Althanasoglou

\footnotetext{
${ }^{1}$ Altunbas et al. (2007) measure bank capital as the ratio of equity over total assets.
} 
et al. 2008; Berger et al. 1997; Goddard et al. 2009; Oral and Yolalan 1990), may hold greater capital buffer.

Thus, since a further analysis is warranted to determine the relationship between capital buffer and bank performance, our second hypothesis is developed as follows:

H2. Bank performance enhances bank capital buffer.

\subsection{Bank risk exposure hypothesis}

During the last decade, regulators have emphasized the importance of capital requirements in order to mitigate risk-taking and enhance the financial stability of the banking industry. The implementation of higher capital requirements aims to create a direct link between banks' capital and risk. It could be the case that banks with a greater risk exposure may have to maintain a higher level of capital (Nier and Baumann 2006). In line with this view, prior literature (Calomiris and Wilson 2004; Flannery and Rangan 2008; Jokipii and Milne 2008, 2011; Rime 2001; Shrieves and Dahl 1992) find a positive relationship between bank capital buffer and risk, indicating that banks with risky positions hold higher buffers. This strand of literature provides evidence supporting the "regulatory hypothesis" according to which regulators encourage banks with a higher risk exposure to hold a higher capital buffer. The reason is that banks that hold risky portfolios but do not maintain a higher buffer are more likely to end up with capital below the minimum requirement.

On the other hand, the "moral hazard hypothesis" proposes a negative relationship between capital and risk. According to this hypothesis, banks might exploit flat-rate 
deposit insurance schemes (Demirgüç-Kunt and Kane 2002). ${ }^{2}$ It could be the case that banks with greater risk exposure may hold lower capital buffer if all depositors are insured. ${ }^{3}$

As the literature it is not conclusive, we test the following hypothesis:

H3. Risk exerts a positive impact on bank capital buffer.

3. Data and variables

We use an unbalanced bank-level panel data that includes saving and commercial banks from EU-27 countries over the period 2004 - 2013 on annual basis. ${ }^{4}$ Our analysis uses 1,017 banks and a total of 3,788 observations. The primary source of our data is the Bankscope database by Bureau van Dijk, while we obtain macroeconomic data from the World Bank.

\subsection{Measuring bank capital buffer}

We define the capital buffer as the amount of capital banks hold in excess of the minimum requirement (Ayuso et al. 2004; Guidara et al. 2013; Jokipii and Milne 2008, 2011). Table 1 and Figure 1 present the variability of total regulatory capital (Tier 1

\footnotetext{
${ }^{2}$ Consistent with this theory, Jacques and Nigro (1997) document a negative association between changes in capital and risk during the first year of the risk-based standards. The authors note that such a result might be due to the methodological issues in the risk-based guidelines where the weights assigned to assets classes might not reflect the true risk.

${ }^{3}$ In line with this theory, Baumann and Nier (2003) employing a sample of listed banks across 32 countries for the period between 1993 and 2000, find that banks located in countries with greater government support and deposit insurance hold lower capital buffer.

${ }^{4}$ In our sample, we include both saving and commercial banks following the study of Casu and Girardone (2010). The authors suggest that mainly commercial and saving banks in European Union form depositary institutions and they have a sufficient degree of cross-country homogeneity and comparability. Previous studies that include both saving and commercial banks in their analysis are Gropp et al. (2010) and Kalyvas and Mamatzakis (2014). In order to account for any differences in the business model between saving and commercial banks, most of these studies employ a dummy variable. In line with these studies, we also include a dummy variable for commercial banks (COM).
} 
plus Tier 2 over Risk Weighted Assets) across country and over time respectively. Following Jokipii and Milne (2008), the calculation of minimum capital requirement for each country is based on Table 2 that presents the national total regulatory capital requirements.

[Insert Table 1, Figure 1 and Table 2]

Table 3 and Figure 2 report descriptive statistics for capital buffer across countries and over time respectively. Data for the years 2004 - 2013 shows that banks hold far more capital than required by the regulators. Banks with the highest mean capital buffer are located in north Europe such as Belgium and Austria (15.35 and 14.59 respectively), while banks with the lowest capital buffer are in Germany (10.89), Croatia (10.92) and Sweden (10.98). The average capital buffer across EU-27 is 11.75. As regards the evolution of buffer over time, we should note that for the period between 2004 and 2006 there is a negative trend (see Figure 2). However, buffer shows a positive development during the period between 2006 and 2010. For the years 2010-2012, the decreasing buffer suggests that European banks had difficulties in maintaining a high capital due to the financial crisis (Avramidis and Pasiouras 2015).

[Insert Table 3 and Figure 2]

\subsection{Measuring bank cost efficiency.}

Previous research has often examined the impact of managerial structure, such as ownership and compensation, on efficiency (Dong et al. 2016; Tzeremes 2015) and to investigate the effects of regulation on bank efficiency (Kalyvas and Mamatzakis 2014; Liu et al. 2012; Pasiouras 2008; Mamatzakis et al. 2015; Mamatzakis and Tsionas, 
2015). Another strand of literature has examined the impact of systematic differences across banks, such as size and risk, on efficiency (Berger and Humphrey 1997; Mamatzakis 2015; Sharma et al 2015), while the association between bank efficiency and market performance has also been investigated (Beccalli et al. 2006; Hadad et al. 2011). In this paper, we derive cost efficiency from a stochastic frontier analysis (SFA). This methodology combines the random error and efficiency in one composite error term (Berger and Humphrey 1997). The cost efficiency model for SFA is the following: $T C_{i, t}=f\left(P_{i, t}, Y_{i, t}, N_{i, t}, Z_{k, t}\right)+v_{i, t}+u_{i, t}$ (1a) where $T C_{i, t}$ stands for the total cost of bank $i$ at year $t, P_{i, t}$ is a vector of inputsand $Y_{i, t}$ is a vector of outputs. $N_{i, t}$ is a vector of quasi-fixed netputs while the vector $Z_{k, t}$ represents country-specific variables. As regards $v_{i, t}$, this term represents factors that affect the total cost function but are beyond the control of the managers. Finally, $u_{i, t}$ stands for the bank inefficiency that is controlled by the managers and follows a halfnormal distribution. The cost efficiency scores lie between 0 and 1 and are calculated according to the below formula:

$$
E F F_{i, t}=\left[\exp \left(-u_{i, t}\right)\right]-1(1 \mathrm{~b})
$$

To enhance flexibility, we resort to the translog cost specification:

$$
\begin{aligned}
\operatorname{lnTC_{i,t}=} & a_{0}+\sum_{i} a_{i} \ln P_{i, t}+\sum_{i} \beta_{i} \ln Y_{i, t}+\frac{1}{2} \sum_{i} \sum_{j} a_{i} \ln P_{i, t} \ln P_{j, t}+ \\
& \frac{1}{2} \sum_{i} \sum_{j} \beta_{i} \ln Y_{i, t} \ln Y_{j, t}+\sum_{i} \sum_{j} \delta_{i, j} \ln P_{i, t} \ln Y_{j, t}+\sum_{i} \zeta \ln N_{i, t}+ \\
& \frac{1}{2} \sum_{i} \sum_{j} \zeta_{i} \ln N_{i, t} \ln N_{j, t}+\frac{1}{2} \sum_{i} \sum_{j} \theta_{i, j} \ln P_{i, t} \ln N_{j, t}+\sum_{i} \sum_{j} \kappa_{i, j} \ln Y_{i, t} \ln N_{j, t}+
\end{aligned}
$$




$$
\begin{aligned}
& \mu_{1} T^{2}+\sum_{i} v_{i} T \ln P_{i, t}+\sum_{i} \zeta_{i} T \ln Y_{i, t}+\sum_{i} \rho_{i} T \ln N_{i, t}+\sum_{i} \varphi_{i} Z_{k, t}+v_{i, t}+ \\
& u_{i, t} \text { (2) }
\end{aligned}
$$

Bank inputs and outputs are defined based on the intermediation methodology (Sealey and Lindley 1977). According to this methodology, the main purpose of banks is to use their labour and capital to accumulate funds and to transform them into loans and other income generating assets. We specify two inputs and two outputs. Inputs consist of labour as measured by the ratio of personnel expenses over total assets $(P 1)$ and financial capital measured as the ratio of total interest expenses over deposits and shortterm funding $(P 2)$. In terms of output prices, we include gross loans $(Y 1)$ and other earning assets (Y2) such as T-bills, bonds, government securities and equity investments. Total cost $(T C)$ is defined as the sum of total interest and non-interest expenses.

We include as quasi-fixed netput the fixed assets of each bank (N1) which stands for a proxy of physical capital. Furthermore, we include equity (N2) as a second qausi-fixed netput. Equity represents an alternative source of funding for banks and therefore, it might affect their cost structure (Fiordelisi et al. 2011; Mamatzakis and Tsionas, 2019; Mamatzakis and Vu 2018; Mamatzakis and Tsionas, 2017).

Furthermore, the translog function includes the time trend $(T)$ to account for technological progress and any potential time effects. Finally, we include countryspecific dummy variables $\left(Z_{k, t}\right)$, to capture country characteristics and cross-country differences.

The variability in bank cost efficiency across country and over time is reported in Table 4 and Figure 3 respectively. Table 4 shows that the average cost efficiency for the sample is around $78 \%$. This indicates that banks need to improve their efficiency by $22 \%$ 
in order to converge to the cost efficiency frontier. At a country level, Hungary, Romania and Bulgaria have the lowest cost efficiency scores with scores of $0.63,0.63$ and 0.64 respectively. Conversely, banks in Malta, Spain and Sweden are the best performers with efficiency scores around $0.85,0.84$ and 0.83 respectively. These scores could be compared to the efficiency scores reported in the previous literature (Casu and Girardone 2010; Kalyvas and Mamatzakis 2014; Mamatzakis and Tsionas, 2019; Mamatzakis and Vu 2018; Mamatzakis and Tsionas, 2017).

Concerning the evolution of bank efficiency over time, Figure 3 indicates an apparent reduction in cost efficiency during the years 2005 - 2008 with the lowest score in 2008 (0.73). The next two years are characterized by a positive trend ( 0.79 in 2009 to 0.81 in 2010). After the year 2010, bank cost efficiency decreases possibly because most of the European banks are exposed to the sovereign debt crisis.

[Insert Table 4 and Figure 3]

Regarding the accounting performance measures, we include ROE that is the return to shareholders on their equity. Our next measure of bank performance is the ROA that reflects the ability of managers to generate profits using banks assets indicating how efficient bank assets are managed. Finally, we employ NIM, which focuses on the profits earned from interest activities.

\subsection{Measuring bank risk exposure}

In this study, we employ various proxies of bank risk exposure. First, we employ the Altman's Z-Score (Altman 1968) as a measure of bankruptcy risk. The Altman's risk measure is derived from balance sheet values and is calculated as follows: 
ALTMANZ $=1.2 X_{1}+1.4 X_{2}+3.3 X_{3}+0.64 X_{5}+0.999 X_{5}(3)$

where $X_{1}$ is the ratio of working capital over total assets. Working capital is calculated as the difference between current assets and current liabilities. Positive values of working capital indicated that the institution can cover its financial obligations. $X_{2}$ is the ratio of retained earnings over total assets and presents a measure of true profitability. $X_{3}$ is the ratio of earnings before interest and taxes over total assets. This measure reflects the cash available for allocation to shareholders, creditors and government. $X_{4}$ is the ratio of market value of equity to book value of liabilities while $X_{5}$ stands for the ratio of sales to total assets and presents the sales generating ability of the bank. Therefore, a greater value of Altman's Z-Score indicate a lower probability of bankruptcy. As an additional measure of bank risk, we also consider an alternative of Altman's Z-Score. We employ ZSCORE as proposed by Boyd and Graham (1986) according to the following formula: ZSCORE $=(1+\mathrm{ROE}) /$ Standard Deviation of ROE. The ZSCORE can be interpreted as an accounting based measure of the distance to default and implies that banks with a lower Z-Score have a higher risk of default. Despite some criticism regarding the Z-Score (Chiaramonte et al. 2016), it is simple to compute using accounting information and data are available to employ it. ${ }^{5}$ In addition, we follow recent literature (see Barry et al. 2011; Bouvatier et al. 2014; Brou and Krueger 2016; Chiaramonte et al. 2016; Guo et al. 2015; Jan and Marimuthu 2015; Lepetit and Strobel 2015; Mamatzakis and Bermpei 2014; Mare et al. 2016; Radic et al.

\footnotetext{
${ }^{5}$ There are some concerns regarding the Z-Score. First it depends on the quality of accounting framework and second, firms may smooth their accounting data and this, in turn, could lead to overassessment of the bank stability. Future research shall opt additional data sets such as... to estimate alternatives to Z-score.
} 
2012; Sharma 2013; Soedarmono et al. 2013) which opts for Z-Score for comparison with the present results ${ }^{6}$

Furthermore, we include the ratio of non-performing loans over total loans (NPL). We expect NPL to have a positive impact on bank capital buffer. Banks with increasing NPL will increase their capital buffer, as they are obligated to hold higher levels of loan loss provisions (Jokipii and Milne 2008). We also include the ratio of Off-BalanceSheet items over total liabilities (OBS) as another measure for bank risk. OBS items are measured as the non-interest income and fee-generating from various contingent liabilities such as derivatives, letters of credit, insurance and other types of nontraditional banking activities and securities underwriting. OBS items increase the risk exposure for a bank and therefore, we expect that banks with a greater amount of OBS items will hold higher a capital buffer. Finally, we include the ratio of risk-weighted assets over total assets (RWA), defined as the total amount of bank's assets weighted for the credit risk according to Basel rules. We consider RWA as a proxy of bank risk as the allocation of bank assets among risk categories would define the quality of bank portfolio risk. (Berger 1995; Jacques and Nigro 1997; Jokipii and Milne 2011). Note that this measure of risk captures mainly bank's exposure to the credit risk (Jokipii and Milne 2011).

\subsection{Other control variables}

\footnotetext{
${ }^{6}$ Data availability issues dictate the choice of our proxies of bank risk exposure. Given the data availability, future research could expand and explore other measures of risk such as bank credit rankings or asset portfolio risk.
} 
As a measure of market discipline, we include a dummy variable DISCLSR that takes the value 1 for listed banks and 0 for unlisted. We expect that the observability of bank's risk choices, as captured by this dummy variable, will increase the incentives for banks to hold regulatory capital above the minimum requirement. The main reasons are first, to reduce the risk of default and second to avoid being penalised by investors for choosing higher risk (Boot and Schmeits 2000; Nier and Baumann 2006).

We also include the explanatory variable SIZE, measured as the natural log of total assets, to detect differences in the level of the capital buffer because of the bank size. Size may have an impact on capital buffer due to the extent of bank diversification, cost of funding and investment opportunities. This relationship could be either positive or negative depending on how small and large banks adjust their capital buffer during the period under study. Size may have a negative impact on capital buffer, as large and well-diversified banks have a smaller probability of a sharp decline in their capital ratios. Moreover, smaller banks may increase their capital buffer in order to accommodate difficulties to access capital markets in case of emergency (Ayuso et al. 2004; Francis and Osborne 2012; Jokipii and Milne 2008). A positive relationship might also exist, in particular, due to the financial crisis of 2008. This positive relationship between bank size and buffer is in line with the "franchise-value hypothesis" according to which bigger banks may reinforce their charter value during difficult times by enhancing their capital. Thus, it could be the case that during the period under study, larger banks, compared to small banks, will take advantage of economies of scale, diversification effects and easier access to capital markets to increase their capital and comply with the minimum requirements. 
We also account for the concentration ratio (C5) in the banking industry by including the sum of the assets of the five largest banks as a share of all banks in each country and for each year. The impact of the concentration ratio on capital buffer could be either positive or negative. The sign depends on whether a low competition will increase or decrease the incentives for a higher capital (Nicoló et al. 2004).

Furthermore, in order to eliminate the potential biases associated with having omitted variables, we employ a dummy variable that takes the value 1 for European Monetary Union countries and 0 otherwise (EMU). In addition, we include time dummies to capture any potential time effects and a dummy variable for commercial banks (COM) to account for any differences between commercial and saving banks (Casu and Girardone 2010). Table I in Appendix provides a brief description of the variables and the data sources, while Table 6 reports summary statistics for the key variables.

\section{[Insert Table I and Table 6]}

\section{Methodology}

\subsection{Dynamic Panel Model}

Following previous studies (Ayuso et al. 2004; Jokipii and Milne 2008), we employ partial adjustment process in order to account for costs of adjustments in the capital buffer. We consider bank-specific variables and country-specific variables as determinants of the capital buffer as analysed in the data section. We apply the two-step system generalized method of moments (GMM) estimator as developed by Arellano and Bover (1995) for a dynamic model of panel data. ${ }^{7}$ This methodology is preferred

\footnotetext{
${ }^{7}$ In this paper with use the xtbond 2 stata command that implements the two-step system GMM estimator with the Windmeijer (2005) correction to the reported standard errors. In the one-step system GMM
} 
for three main reasons. First, by taking the first differences for all variables, we eliminate the presence of any unobserved bank-specific effects. Second, we use the lagged dependent variable to capture the dynamic nature of capital buffer and third, by using GMM methodology, we account for the potential endogeneity of the explanatory variables. We consider as exogenous the country-specific variables and time dummies and as endogenous the bank-specific variables (Ayuso et al. 2004). The instruments chosen for the lagged endogenous variables are two-to-six period lags of the same variables. Furthermore, the results of the two-step system GMM estimator are tested by Hansen's J diagnostic test for instrument validity and the test for the second-order autocorrelation of the error terms as suggested by Arellano and Bond (1991). Finally, we account for Windmeijer (2005) biased-corrected robust standard errors.

The model that we examine is the following:

$$
\begin{aligned}
B U F F_{i, t}= & \beta_{0}+\beta_{1} \text { BUFF }_{i, t-1}+\beta_{2} \text { EFF }_{i, t}+\beta_{3} \text { ALTMANZ }_{i, t}+\beta_{4} \text { ZSCORE }_{i, t}+ \\
& \beta_{5} N P L_{i, t}+\beta_{6} \text { OBS }_{i, t}+\beta_{7} R W A_{i, t}+\beta_{8} \text { DISCOSURE }_{i, t}+\beta_{9} \operatorname{SIZE}_{i, t}+ \\
& \beta_{10} \text { COM }_{i, t}+\beta_{11} C_{i, t}+\beta_{12} \text { GDPGR }_{i, t}+\text { time effects }+u_{i, t}
\end{aligned}
$$

where the lagged value of the dependent variable $\left(B U F F_{i, t-1}\right)$ captures the importance of adjustment costs and we expect a positive and significant coefficient for this variable as stated in the hypothesis H1. EFF $F_{i, t}$ stands for bank efficiency, $A L T M A N Z_{i, t}$ is Altman's Z-Score calculated according to Altman (1968) and measures the bank's risk for bankruptcy, $Z S C O R E_{i, t}$ is an additional measure bank risk presenting the distance

robust standard errors are reported which are robust to heteroscedasticity. In two-step GMM error terms are already robust and Windmeijer (2005) correction is implemented to standard errors. Two-step uses the consistent variance co-variance matrix from first step GMM to reconstruct the weight matrix. Without this correction, the standard errors tend to be downward biased. 
from default. Other risk determinants that can affect bank capital buffer and we account for are $N P L_{i, t}$ measured as the ratio of non-performing loans to total assets, $O B S_{i, t}$ which is the ratio of off-balance-sheet items to total liabilities and $R W A_{i, t}$ which stands for the ratio of risk-weighted assets to total assets.

We also consider the impact of market discipline employing the variable $\operatorname{DISCOSURE}_{i, t}$ that takes the value one for listed banks and 0 for unlisted. $S I Z E_{i, t}$ stands for bank size measured as the natural $\log$ of total assets. $C O M_{i, t}$ is an indicator variable that takes the value 1 for commercial banks and 0 otherwise, $C 5_{i, t}$ is the concentration ratio for the banking industry calculated as the sum of the assets of the five largest banks as a share of all banks in each country, GDPGR $R_{i, t}$ us the GDP growth in each country and $E M U_{i, t}$ is an indicator variable that takes the value 1 for European Monetary Union country and 0 otherwise. We also consider for time effects including a set of time dummies to capture the unobserved time effects. The error term $u_{i, t}$ consists of a bank-specific component $\mu_{i}$, which is assumed to be constant over time and a white noise $\varepsilon_{i, t}$. Hence, $u_{i, t}=\mu_{i}+\varepsilon_{i, t}$ where $\mu_{i} \sim$ iid $\left(o, \sigma_{\mu}^{2}\right)$ and $\varepsilon_{i, t} \sim \operatorname{iid}\left(o, \sigma_{\varepsilon}^{2}\right)$.

\subsection{Dynamic panel threshold model}

Given the financial crisis of 2007 - 2008, we opt for a novel methodology that enables us to identify any potential regime changes in the relationship between capital buffer, bank performance and risk-taking. We employ the threshold methodology proposed by Hansen (1999) and developed by Kremer et al. (2013). This methodology uses the crosssectional model employed by Caner and Hansen (2004), where the authors allow for endogeneity by using GMM estimators. Kremer et al. (2013) extended threshold 
analysis to a dynamic unbalanced methodology that identifies possible changes in the coefficient of the independent variables.

We employ the following threshold model:

$B U F F_{i, t}=\mu_{i}+\lambda_{1} m_{i, t} I\left(X_{i, t} \leq \gamma\right)+\delta_{1} I\left(X_{i, t} \leq \gamma\right)+\lambda_{2} m_{i, t} I\left(X_{i, t}>\gamma\right)+\varepsilon_{i, t}$

The subscript $i$ refers to the individual banks and the subscript $t$ indexes the time. $B U F F_{i, t}$ is the dependent variable, $\mu_{i}$ is the bank-specific fixed effect and $\lambda_{1}$ and $\lambda_{2}$ the reverse regression slopes and based on these slopes we assume two regimes. $X_{i, t}$ is the threshold variable and $\gamma$ is the threshold value, which distribute the observations above and below the threshold value composing the high and low regimes respectively. $I$ is the indicator function that specifies the two regimes as defined by the threshold variable. Finally, $\varepsilon_{i, t}$ is the error term, which is assumed to be independent and identically distributed (iid) with mean zero and finite variance $\sigma^{2}$. The model employed by Kremer et al. (2013) treats $m_{i, t}$ as a vector of explanatory variables that includes a subset $m 1_{i, t}$ of exogenous variables uncorrelated with $\varepsilon_{i, t}$ and a subset $m 2_{i, t}$ of endogenous variables correlated with $\varepsilon_{i, t}$. Furthermore, Kremer et al. (2013) extend Hansen's (1999) work by accounting for the regime dependent variable $\delta_{1}$ which represents the differences in the regime intercepts. According to Bick (2010), we include $\delta_{1}$ as disregarding the regime intercepts would lead to biased estimates for both the regime coefficients and the threshold value.

In the first step, in order to estimate the predicted values, Kremer et al. (2013) following Caner and Hansen (2004) uses the reduced form of regressions for the endogenous variable as a function of instruments. In step two, the threshold value $\gamma$ is estimated by 
using the predicted values of the endogenous variables in Eq. (5). In the third step, to obtain the slope parameters $\lambda_{1}$ and $\lambda_{2}$, Eq. (5) is estimated via GMM for the threshold value $\gamma$, where the threshold variable is replaced by its predicted values calculated in the second step. According to Caner and Hansen (2004), the optimal threshold is estimated via a minimizer of the sum of squared errors by using 2SLS estimator. Following Caner and Hansen (2004) and Hansen (1999), the 95\% confidence interval of the threshold value is given by the $\Gamma=[\gamma: L R(\gamma) \leq C(\alpha)]$. Here, $C(\alpha)$ indicates the asymptotic distribution of the likelihood ratio $(L R)$ statistic at $95 \%$ significance level.

\section{Empirical Results}

\subsection{Panel regression results}

We first propose to examine the association between capital buffer, performance and risk employing dynamic panel regressions for the model specified in equation (4). We start our analysis with this methodology to capture the dynamic nature of capital buffer and to account for the potential endogeneity of the explanatory variables. Besides the dynamic panel analysis, we propose a threshold methodology that identifies potential regime switches in the underlying relationships, while at the same time it maintains all the advantages of the dynamic panel analysis as discussed previously. Therefore, our main motivation for the use of the threshold analysis is to identify any changes in the relationships between the variables because of the financial crisis of 2008 .

Dynamic panel results are presented in Table 6 and 7. In Table 6, we use the cost efficiency as a performance measure. We add the control variables gradually to see the individual impact of the main variables. Model (3) includes ALTMANZ as the main measure of bank risk, while in Model (4) we use ZSCORE as part of sensitivity analysis 
of an alternative bank risk measure. Next, in Models (5) - (7) we employ NPL, OBS and RWA variables respectively. Finally, Model (8) accounts for all bank and countryspecific variables simultaneously. The cost of adjustment as captured by the coefficient of the lagged dependent variable $B U F F_{i, t-1}$ is positive and highly significant in all specifications. These results confirm hypothesis H1 suggesting that banks need time to adjust their current capital buffer. The coefficient of $B U F F_{i, t-1}$ changes across different models when we include other control variables. Adding all bank and country-specific variables in Model (8), the speed of adjustment increases from 0.188 in Model (1) to 0.572 in Model (8). The speed of adjustment of 0.572 in Model (8) indicates that when we account for other determinants of bank capital buffer, banks converge to the target buffer with a rate of $57.2 \%$ per annum.

In terms of regression estimates, the coefficient of cost efficiency (EFF) is positive and significant at $1 \%$ level (see Models (2) and (7)). In Model (8) which includes all control variables, EFF exerts a positive impact on bank capital buffer at 5\% level. These results are in line with our second hypothesis $\mathrm{H} 2$ indicating that higher efficiency leads to a greater capital accumulation (Fiordelisi et al. 2011). This finding is in agreement with the pecking order theory which argues that institutions prefer to use internal sources of funding rather than external sources (Myers and Majluf 1984). Furthermore, this positive relationship between bank efficiency and capital buffer could be explained by the "franchise-value hypothesis" according to which due to the income effect of high 
cost efficiency, banks will choose to hold a higher capital to protect their reputation and charter value (Berger and Bonaccorsi di Patti 2006). ${ }^{8}$

As regards the impact of bank risk measures on capital buffer, ALTMANZ carries a positive and highly significant coefficient in Model (3) and Model (8). This positive relation between ALTMANZ and BUFF suggests that banks that are less likely to default (lower risk) hold a greater capital buffer. Note that this relationship is significant at $1 \%$ in Model (8). These findings reinforce the "franchise-value hypothesis". Stable banks with a lower risk of default have higher charter value (Jokipii and Milne 2011) and therefore, banks with high Z-Score will sustain their value by maintaining a higher capital buffer.

The OBS variable exerts a positive impact on bank capital buffer at 10\% level in Models (6) and (8) providing evidence for hypothesis H3 and supports the "regulatory hypothesis" according to which banks with greater off-balance sheet activities prefer to hold higher capital buffer as a cushion against unexpected losses. We also report a positive and at $1 \%$ level significant coefficient for the bank size. Existing literature (Ayso et al. 2004; Guidara et al. 2013; Jokipii and Milne 2008; Stolz and Wedow 2011) provide evidence for the too-big-to-fail phenomenon according to which larger banks expect government support in an event of distress and thereby might keep lower capital buffer. Furthermore, according to this strand of literature, larger banks benefit from economies of scale and diversification effects. Therefore, larger banks have easier access to capital markets and a lower probability of a sharp drop in their capital ratios.

\footnotetext{
${ }^{8}$ Franchise or charter value of a bank is defined as the value that would be foregone due to a bankruptcy. According to this theory there is ambiguous relationship between bank capital and risk taking. The higher risk can increase the probability of default and therefore encourage banks to raise their capital. This has been broadly discussed by Boot and Schmeits (2000).
} 
In contrast, small banks might need to maintain a greater capital buffer to deal with difficulties to draw on capital markets. In this study, which covers the years of the financial meltdown of 2007 -2008, we report results that are in line with the "franchisevalue hypothesis". Thus, larger institutions would protect their sustainability during difficult periods by ensuring their capital adequacy. ${ }^{9}$

All models pass the Hansen standard validity tests of the instruments used in the regressions. Moreover, $\mathrm{AR}(2) \mathrm{p}$-values reject the presence of second-order correlation in the error terms, as should be if the residuals in levels are white noise.

\section{[Insert Table 6]}

In a further analysis, we use dynamic panel regressions to examine the relationship between capital buffer and performance. Model (1) in Table 7 employs bank efficiency, Model (2) uses the ROE as an indicator of bank profitability, Model (3) examines the relationship between the capital buffer and ROA while Model (4) includes NIM. Models (5) - (7) report the simultaneous impact of the efficiency and one of the other performance measures on buffer.

Model (2) documents a positive relationship between ROE and capital buffer at $1 \%$ level. Consistent with the impact of EFF on buffer in Table (6), this result provides further evidence for both the "franchise-value hypothesis" and the pecking order theory. Therefore, more profitable banks that accumulate equity through retained earnings, may hold greater capital buffer, especially when raising capital is difficult. Arguably, less

\footnotetext{
${ }^{9}$ Banks that violate the minimum capital requirements lose part of their charter value (Flannery and Rangan 2004; Stolz and Wedow 2011). Thus, larger banks will take advantage of the economies of scale, diversification effects and the easier access to capital markets to maintain a higher capital buffer.
} 
profitable banks suffering from a greater cost of issuing equity might maintain a lower capital buffer. These results could be compared with those obtained from Nier and Baumann (2006) who suggest that ROE can enhance capital buffer. Similar results documenting a positive relationship between profitability and capital have been found in Berger (1995) and Flannery and Rangan (2008) for the 1980s and 1090s respectively. ${ }^{10}$

As regards the impact of the other control variables on buffer, after employing ROE as a performance measure, ALTMANZ and SIZE maintain their positive and highly significant impact on buffer. The significant coefficient of ALTMANZ indicates that even when we account for bank performance with ROE, lower likelihood of bankruptcy leads to higher capital buffer. The positive coefficients of NPL and OBS in Models (4) - (7) provide evidence in favour our hypothesis $\mathrm{H} 3$ for a positive relationship between risk and capital buffer supporting the "regulatory hypothesis".

Next, Models (5) - (6) report the impact of bank efficiency on buffer when we include additional measures of performance. Models (5) - (7) employ both EFF and one of the other accounting performance measures (ROE, ROA and NIM) in the regressions. Estimated results suggest that even when we account for other accounting performance measures, bank efficiency exerts a positive and at least at 5\% level significant impact on the capital buffer. These findings imply that the inclusion of other performance measure does not affect our regression results.

\footnotetext{
${ }^{10}$ Alfon et al. (2004), Ayuso et al. (2004) and Jokipii and Milne (2008) document a negative association between capital and past values of the return on equity. In this strand of literature the return on equity is used as an indicator of bank's cost of raising equity capital. However, in this study and consistent with Berger (1995), Nier and Baumann (2006) and Flannery and Rangan (2008) the return on equity is used as an indicator of firm profitability.
} 
[Insert Table 7]

\subsection{Threshold estimations}

\subsubsection{The capital buffer and efficiency nexus}

Our sample for threshold estimation consists of 1,735 observations for 314 banks over the period 2005-2013. The results for the empirical relationship between buffer and efficiency are presented in Table 8. We find a threshold variable of 0.729 for bank efficiency. This threshold value splits our sample into two regimes. The low regime includes 468 banks with efficiency scores less than 0.729 . The estimated coefficient $\lambda_{1}$ indicates that for banks that fall in the low efficiency regime, efficiency exerts a positive impact on buffer at $1 \%$ level. This result suggests that for the relatively less efficient banks, an increase in efficiency enhances bank capital buffer. The high regime consists from 1267 banks with efficiency scores greater than the threshold value. The negative sign of the estimated coefficient $\lambda_{2}$ implies that for banks in the high regime, efficiency has a negative impact on buffer at $5 \%$ level.

A striking result of this analysis is that the relationship between buffer and efficiency is characterized by a structural breakpoint, indicating that the impact of efficiency on capital buffer depends on the level of bank's efficiency. The positive coefficient for banks falling in the low regime suggests that the relatively less efficient banks use their increased efficiency to accumulate higher capital buffer. This finding confirms hypothesis $\mathrm{H} 2$ and is in line with the "franchise-value hypothesis". According to this theory, banks that are more efficient tend to hold a higher capital to protect their future income derived from high efficiency (Berger and Bonaccorsi di Patti 2006). Conversely, the negative coefficient for the relatively more efficient banks provides evidence in 
favour of the "efficiency-risk hypothesis" suggesting that a higher level of efficiency might substitute to capital against unexpected losses (Berger and Bonaccorsi di Patti 2006). These findings are in agreement with Altunbas et al. (2007), Berger and Bonaccorsi di Patti (2006) and Kwan and Eisenbeis (1997) who document a negative relationship between capital and efficiency. Furthermore, our results are similar to Ayuso et al. (2004) and Jokipii and Milne (2008) who find an inverse relationship between bank performance and capital buffer.

Overall, this study complements prior literature on the association between bank capital buffer and efficiency documenting a breakpoint in the underlying relationship. We show that for the relatively less efficient banks (low regime) the capital buffer choice dominates over the substitution effect, suggesting that relatively less efficient banks choose to maintain more capital buffer to protect their franchise value. In contrast, for the relatively more efficient banks (high regime), the substitution effect dominates over the capital buffer choice as an increasing efficiency may substitute for capital in protecting the firm from financial distress.

In line with the results obtained from the dynamic panel regressions in Table 7 , the coefficient of the lagged value of capital buffer (Lag Buffer) is positive at $1 \%$ level, confirming hypothesis H1. Furthermore, Altman's Z-Score carries a positive and at 1\% significant level coefficient suggesting that banks with a lower risk of default accumulate greater capital buffer. RWA exerts a negative impact on buffer at $1 \%$ level indicating that banks with a greater portfolio of risk-weighted assets face difficulty in increasing their capital above the minimum requirements. The negative relationship between buffer and RWA also suggests that banks are forced to increase their capital 
buffer by reducing their risk-weighted assets (Shim 2013). Finally, the positive impact of bank size on capital buffer suggests that larger banks might hold higher buffer as a sign of solvency due to their easier access to capital markets.

\section{[Insert Table 8]}

Table 9 presents the evolution of banks in low and high regimes for the period 2005 2013. One can notice a negative trend in the percentage of banks with relatively higher efficiency scores for the years 2006 - 2008 (90\% in 2005 decreases to $88 \%$ in 2006 to $82 \%$ in 2007 and $65 \%$ in 2008). Although, for the years $2009-2010$ there is a significant recovery in the number of banks that fall in the high efficiency regime (from $65 \%$ in 2008 to $75 \%$ in 2009 and $80 \%$ in 2010), the trend in the following years is negative. These results are supported by the impact of the financial crisis of $2007-2008$ on the banking sector. The reduction in the number of banks with efficiency above the threshold value mirrors the deteriorating performance of banks during the crisis.

[Insert Table 9]

In a further analysis, we account for the impact of the capital buffer on bank efficiency. Therefore, we employ the threshold methodology using the buffer as a threshold variable and the efficiency as a dependent variable. The impact of the buffer on efficiency is presented in Table 10. The estimated buffer threshold is 13.594 . The low regime consists of 1,273 banks with relatively low capital buffer while the high regime consists of 462 banks. The coefficient $\lambda_{2}$ for banks in the high regime is significant at 5\% level. Our findings could be compared with those of Fiordelisi et al. (2011) who find that an increase in bank capital leads to an efficiency improvement and with and 
Kwan and Eisenbeis (1997) who show that better capitalized banks exhibit higher level of efficiency than less-capitalized banks.

Furthermore, the negative and significant at $1 \%$ level coefficient of Altman's Z-Score may suggest that banks with a lower risk of default do not consider that much cost efficiency leading to lower efficiency scores. RWA exerts a negative impact on efficiency at $1 \%$ level. The impact of bank size on efficiency is negative implying that bank efficiency decreases as bank size increases. ${ }^{11}$

\section{[Insert Table 10]}

The evolution of banks in the low and high regimes over the sample period is presented in Table 11. It is obvious that the percentage of banks classified in low regime is consistently above the percentage of banks in the high regime. Table 11 shows a negative trend in the percentage of banks with high capital buffer for the years between 2006 and 2008 ( $27 \%$ in 2006 to $21 \%$ in 2007 and $23 \%$ in 2008). These results could be explained by the high cost of raising capital during distress (Campbell 1979). Our findings suggest that the ability of banks to accumulate regulatory capital over the minimum requirement has deteriorated due to the financial crisis of $2007-2008$.

[Insert Table 11]

\subsubsection{The capital buffer and Altman's Z-Score nexus}

We further examine the relationship between bank capital buffer and risk of default as measured by the Altman's Z-Score. High values of Altman's Z-Score indicate more

\footnotetext{
${ }^{11}$ This finding is supported by Stiroh and Rumble (2006) who show that size is negatively correlated with efficiency for both domestic and foreign banks. The authors explain this relation through the agency costs, bureaucratic processes and other costs of managing extremely large institutions.
} 
stable banks and thus, lower risk of default. Table 12 presents threshold estimation results using the buffer as the dependent variable and Altman's Z-Score as the threshold regime variable. The threshold value for the Altman's Z-Score is 7.382. This value splits our sample into the low regime, which consists of banks with relatively greater risk of default, and the high regime consisting of more stable banks. The coefficient $\lambda_{1}$ is positive and significant at $1 \%$ level while the impact of Altman's Z-Score on capital buffer is insignificant for banks in the high regime. These results are in line with those obtained by the dynamic panel regressions in Table 7, indicating that banks with relatively lower Altman's Z-Score and therefore, a higher risk of default, will choose to hold a higher capital buffer. Our findings provide evidence for the "regulatory hypothesis" according to which regulators encourage banks with a higher risk exposure to hold a higher capital buffer.

Concerning the impact of the other bank-specific variables on buffer, the estimated results in Table 12 are in line with those of Table 8 where the threshold variable was the efficiency. The lagged value of buffer, efficiency, non-performing loans and bank size exert a positive impact on capital buffer. Finally, RWA carries a negative and $1 \%$ significant sign, suggesting that a greater portfolio of risky assets curbs bank's ability to accumulate capital above the minimum requirements.

\section{[Insert Table 12]}

The evolution of banks in low and high regimes over time is presented in Table 13. The percentage of banks in the low regime is above the percentage of banks in the high regime. These results could mirror the negative impact of the financial crisis of $2007-$ 
2008 showing that over this period at least the $70 \%$ of the banks in our sample are characterized with relatively greater likelihood of default.

\section{[Insert Table 13]}

To examine the impact of capital buffer on bank default risk, we employ the threshold methodology using Altman's Z-Score as the dependent variable and buffer as the threshold regime variable. Table 14 presents the estimated results. The threshold value of capital buffer is 9.244 and splits our sample in the low regime that consists of banks with relatively low buffer and the high regime with the relatively well-capitalised banks. Both regime-dependent coefficients $\left(\lambda_{1}\right.$ and $\left.\lambda_{2}\right)$ of buffer are positive and significant at $10 \%$ and $1 \%$ level respectively.

These findings show that an increase in buffer increases Altman's Z-Score and therefore, decreases the risk of default. Our results are in line with Kwan and Eisenbeis (1997) and Guidara et al. (2013) who find that better-capitalized banks tend to have lower risk exposure. More importantly, these results suggest that the greater the minimum capital requirement, the weaker the incentives for banks to engage in risky activities leading to a lower risk of default. Therefore, these results support that the implementation of minimum capital requirements by Basel Committee, has succeeded in its main aim of enhancing bank stability.

[Insert Table 14]

Finally, Table 15 shows that the percentage of the relatively well-capitalised banks is above that of the relatively low capitalized. After the year 2007, there is a negative trend 
( $90 \%$ in 2005 to $85 \%$ in 2007). This might be due to the costly capital during the crisis of 2007 - 2008 that renders difficult for banks to increase their regulatory capital.

\section{[Insert Table 15]}

\section{Sensitivity analysis: A panel-VAR model}

As part of sensitivity analysis that takes into account possible endogeneity among the main variables of our modelling, we employ a panel-VAR model where all main variables (i.e. except control variables) enter a system of equations as endogenous. Such model would facilitate the identification of causality directions between the main variables in a dynamic way. As a first step, we need to decide the optimal lag order $j$ of the variables. We seek for the optimal lag order following Lutkepohl (2006). We also apply the Akaike Information Criterion (AIC) and the Arellano-Bond AR tests. The optimal lag identified is equal to one. Sargan test reports for lag equals to one the null hypothesis is not rejected. ${ }^{12}$ Therefore, we employ a panel-data autoregression methodology by using a first order $3 \times 3$ panel-VAR model following Love and Zicchino $(2006)^{13}$

$X_{i t}=\mu_{i}+\Phi X_{i t-1}+e_{i, t}, i=1, \ldots, \mathrm{N}, t=1, \ldots, \mathrm{T}(8)$

Where $\mathrm{X}_{\mathrm{it}}$ is a vector of three main variables of this analysis that is the bank capital buffer, bank efficiency and Altman's Z-Score. Thus, $\Phi$ indicates a matrix of coefficients (3x3), whilst $\mu_{\mathrm{i}}$ a vector of bank-specific effects and $e_{i, t}$ iid residuals. For estimation purposes, to account for endogeneity we follow Love and Zicchino (2006) employing

\footnotetext{
${ }^{12}$ Results are available upon request. Note that the ordering of variables could also be of importance. We test for the reverse ordering and results remain similar. Results are available under request.

${ }^{13}$ Note that without loss of generality we could estimate a panel VAR $4 \times 4$, and so on.
} 
the Arellano-Bond system-based GMM estimator. Essentially, the panel-VAR is a system of the following equations:

$$
\begin{aligned}
& \text { BUFF }_{i t}=\beta_{10}+\sum_{j=1}^{J} \beta_{11} B_{U F F}+F_{i t-j}+\sum_{j=1}^{J} \beta_{12} E F F_{i t-j}+\sum_{j=1}^{J} \beta_{13} A_{L T M A N Z_{i t-j}}+e_{1 i, t} \\
& \text { EFF }_{i t}=\beta_{20}+\sum_{j=1}^{J} \beta_{21} \text { BUFF }_{i t-j}+\sum_{j=1}^{J} \beta_{22} E F F_{i t-j}+\sum_{j=1}^{J} \beta_{23} \text { ALTMANZ }_{i t-j}+e_{2 i, t} \\
& \text { ALTMANZ }_{i t}=\beta_{30}+\sum_{j=1}^{J} \beta_{31} \text { BUFF }_{i t-j}+\sum_{j=1}^{J} \beta_{32} E F_{i t-j}+\sum_{j=1}^{J} \beta_{33} \text { ALTMANZ }_{i t-j}+e_{3 i, t}
\end{aligned}
$$

The above system of equations has a moving average (MA) representation as a function of a set of present and past residuals $e_{1}, e_{2}$, and $e_{3}$. Given possible endogeneity, these equations could be correlated and thereby the coefficients of the MA representation are not meaningful. A way to have meaningful estimations is to orthogonalise the residuals opting for the Cholesky decomposition of the covariance matrix. In addition, we introduce fixed effects to ensure heterogeneity in the levels. ${ }^{14}$

\subsubsection{Panel Impulse response functions (IRFs)}

Figure 4 presents impulse-response functions (IRFs) and the 5\% error banks generated by Monte Carlo simulation for a panel VAR of the following ordering of variables Altman's Z-Score (ALTMANZ), bank efficiency (EFF) and capital buffer (BFF). ${ }^{15}$

\section{[Insert Figure 4]}

\footnotetext{
${ }^{14}$ Following Love and Zicchino (2006) we apply the Helmert procedure in the data set. That is the data we are forward mean differenced.

${ }^{15}$ As the ordering of variables in the panel VAR is not without significance we also estimate the system of equations, opting for the reverse ordering of variables. Results remain are available under request and confirm the present findings.
} 
From the first row of Figure 4, the last plot shows that the effect of one standard deviation shock of Altman's Z-Score on the buffer is positive, while this effect becomes less pronounced after the fourth year. This result is in line with the main results in Tables 6 and 7 providing further support for the "franchise-value hypothesis". According to this hypothesis, banks with a lower risk of default have higher charter value (Jokipii and Milne 2011) and will sustain their value by holding a higher capital buffer.

Next, one can notice from the second row, last plot that the response of the capital buffer to one standard deviation shock of efficiency is positive as well. It picks after the first two periods and converges to the equilibrium thereafter. These results are in line with our main results obtained in Tables 6 and 7. Thus, the "franchise-value hypothesis" dominates over the "efficiency-risk hypothesis" indicating that banks with higher efficiency choose to hold a higher buffer to protect their charter value and future earnings.

In the case of Altman's Z-score, the panel-VAR methodology appears to confirm the findings of Table 14 (see Figure 4, the first plot in the last row that reports the response of Altman's Z-Score to one standard deviation shock of buffer). The response is positive across the whole period and in agreement with the positive coefficients $\lambda_{1}$ and $\lambda_{2}$ of both regimes in Table 14. Thus, the panel-VAR results show that a higher capital buffer enhances bank stability by reducing the risk of default (increasing Altman's Z-Score). Finally, the second plot in the third row of Figure 4 shows that the effect of one standard deviation shock of buffer on efficiency is negative and it converges towards the equilibrium after the first period. This finding comes in contrast with our previous 
results in Table 10. However, this result needs to be interpreted with some caution as the response crosses the zero line and might imply a loss of significance.

Next, we present VDCs, which show the percent of the variation in one variable that is explained by the shock to another variable, accumulated over time. The variance decompositions show the magnitude of the total effect. We report the total effect accumulated over 10 years. Longer time horizons produced equivalent results. Table 16 presents the VDCs estimations. These results come in agreement with those reported by the IRFs, and provide further evidence that the level of efficiency explains the variation of buffer, though mostly it is buffer itself that explains its variation. Particularly, $3.43 \%$ of the forecast error of capital buffer after ten years is explained by shocks in the EFF variable. Furthermore, the VDCs results show that the level of buffer explains almost the half $(50.8 \%)$ of the variation of efficiency. Finally, both capital buffer and efficiency are significant determinants of bank's risk of default. Around $17.75 \%$ of the forecast error variance of ALTMANZ after 10 years is captured by BFF disturbances and about $26.33 \%$ by EFF disturbances.

[Insert Table 16]

\section{Conclusion}

This study empirically addresses the association between bank capital buffer, performance and risk. Using a sample of EU-27 banks over the period between 2004 and 2013, the findings of this study could be of interest to both supervisory authorities and bank managers. Given that our sample covers the financial crisis of 2007 - 2008, we employ the dynamic panel threshold methodology as developed by Kremer et al. (2013). Results show different regimes over the sample period. A strong positive impact 
of bank performance on the capital buffer is reported for banks in the low performance regime, while for the relatively better performing banks an improvement in the performance decreases the capital buffer. Moreover, threshold results indicate a positive impact of buffer on bank performance. These findings provide evidence that the regulatory framework as regards the capital adequacy requirements can enhance bank performance. Furthermore, threshold analysis shows that capital buffer exerts a strong positive impact on bank stability. The positive relationship between buffer and Altman's Z-Score suggests that the implementation of minimum capital requirements might have succeeded in its main aim of creating a more stable banking system and reducing banks' default risk.

Notably, we find changes in the percentage of banks in each threshold regime during and after the financial crisis of 2007 - 2008. There is an increasing trend in the percentage of banks in the low performance regime over time, especially after the years 2007 - 2008. This finding indicates that banks in the EU-27 region experienced a period of substantial performance deterioration. Moreover, the number of banks in the low capital buffer regime is consistently above the number of banks in the high regime during the financial crisis. Given the high cost of raising capital during the economic downturn, EU-27 banks accumulate lower capital during the recession period. These results are of some value for managers and policy makers in particular. Our findings clearly indicate that the impact of capital requirements is different for banks with different performance and risk characteristics. 
References

Alali F, Jaggi B (2011) Earnings versus capital ratios management: Role of bank types and SFAS 114. Rev Quant Financ Acc 36:105-132

Albertazzi U, Gambacorta L (2009) Bank profitability and the business cycle. J Financ Stab 5:393-409

Alfon I, Argimon I, Bascuñana-Ambrós P (2004) What determines how much capital is held by UK banks and building societies?. London: Financial Services Authority.

Altman EI (1968) Financial ratios, discriminant analysis and the prediction of corporate bankruptcy. J Financ 23:589-609

Altunbas Y, Carbo S, Gardener EPM, Molyneux P (2007) Examining the Relationships between Capital, Risk and Efficiency in European Banking. Eur Financ Manag 13:49-70

Arellano M, Bover O (1995) Another look at the instrumental variable estimation of error-components models. J Econometrics 68:29-51

Athanasoglou PP, Brissimis SN, Delis MD (2008) Bank-specific, industry-specific and macroeconomic determinants of bank profitability. J Int Financ Market Instut Money 18:121-136

Avramidis P, Pasiouras F (2015) Calculating systemic risk capital: A factor model approach. J Financ Stab 16:138-150

Ayuso J, Pérez D, Saurina J (2004) Are capital buffers pro-cyclical?: Evidence from Spanish panel data. J Financ Intermed, 13:249-264

Barry TA, Lepetit L, Tarazi A (2011) Ownership structure and risk in publicly held and privately owned banks. J Bank Financ 35:1327-1340

Baule R (2014) Allocation of risk capital on an internal market, Eur J Oper Res 234:186196

Baumann U, Nier E (2003) Market discipline and financial stability: some empirical evidence. Financ Stab Rev 14:134-141

Beccalli E, Casu B, Girardone C (2006) Efficiency and stock performance in European banking. J Bus Finance Account 33:245-262

Berger AN, (1995) The relationship between capital and earnings in banking. J Money Credit Bank 27:432-456

Berger AN, Bonaccorsi di Patti E (2006) Capital structure and firm performance: A new approach to testing agency theory and an application to the banking industry. $\mathrm{J}$ Bank Financ 30:1065-1102

Berger AN, Humphrey DB (1997) Efficiency of financial institutions: International survey and directions for future research. Eur J Oper Res 98:175-212

Berger AN, Leusner JH, Mingo JJ (1997) The efficiency of bank branches. J Monet Econ 40:141-162

Bick A (2010) Threshold effects of inflation on economic growth in developing countries. Econ Lett 108:126-129

Boot AWA, Schmeits A (2000). Market Discipline and Incentive Problems in Conglomerate Firms with Applications to Banking. J Financ Intermed 9:240273

Bouvatier V, Lepetit L, Strobel F (2014) Bank income smoothing, ownership concentration and the regulatory environment. J Bank Financ 41:253-270 
Brou FB, Krueger TM. (2016) Continental and National Differences in the Financial Ratios of Investment Banking Companies: An Application of the Altman Z Model. J Acc Finance 16:37

Buser SA, Chen AH, Kane EJ (1981) Federal Deposit Insurance, Regulatory Policy, and Optimal Bank Capital. J Financ 36:51-60

Calormiris CW, Wilson B (1998) Bank Capital and portfolio management: The 1930's capital crunch and scramble to shed risk (No. w6649). National Bureau of Economic Research.

Campbell TS (1979) Optimal Investment Financing Decisions and the Value of Confidentiality. J Financ Quant Anal 14:913-924

Caner M, Hansen BE (2004) Instrumental Variable Estimation of a Threshold Model. Econometric Theory 20:813-843

Casu B, Girardone C (2010) Integration and efficiency convergence in EU banking markets. Omega 38:260-267

Chiaramonte L, Poli F, Zhou M (2016). How Accurately Can Z-score Predict Bank Failure?. Financ Market Inst Instrum 25:333-360

Chu L, Mathieu R, Robb S, Zhang P (2007) Bank capitalization and lending behavior after the introduction of the Basle Accord. Rev Quant Financ Acc 28:147-162

Demirgüç-Kunt A, Kane E (2002) Deposit insurance around the world: where does it work? J Econ Perspect 16:175-195

Dong Y, Firth M, Hou W, Yang W (2016) Evaluating the performance of Chinese commercial banks: A comparative analysis of different types of banks, Eur J Oper Res 252:280-295

Fiordelisi F, Marques-Ibanez D, Molyneux P (2011) Efficiency and risk in European banking. J Bank Financ, 35:315-1326

Flannery M, Rangan K (2008) What caused the bank capital build-up of the 1990s? Rev Financ 12:391-429

Francis WB, Osborne M (2012) Capital requirements and bank behavior in the UK: Are there lessons for international capital standards? J Bank Financ 36:803-816

Furfine C (2001) Bank portfolio allocation: the impact of capital requirements, regulatory monitoring, and economic conditions. J Financ Serv Res 20:33-56

Goddard J, Liu H, Molyneux P, Wilson JO (2013) Do bank profits converge?. Eur Financ Manag 19:345-365

Gropp R, Heider F (2010) The Determinants of Bank Capital Structure. Rev Financ 14:587-622

Guidara A, Lai VS, Soumaré I, Tchana FT (2013) Banks' capital buffer, risk and performance in the Canadian banking system: Impact of business cycles and regulatory changes. J Bank Financ 37:3373-3387

Guo L, Jalal A, Khaksari S (2015) Bank executive compensation structure, risk taking and the financial crisis. Rev Quant Financ Acc 45:609-639

Hadad MD, Hall MJ, Kenjegalieva KA, Santoso W, Simper R (2011) Banking efficiency and stock market performance: an analysis of listed Indonesian banks. Rev Quant Financ Acc 37:1-20

Hansen BE (1999) Threshold effects in non-dynamic panels: Estimation, testing, and inference. J Econometrics 93:345-368

Jacques K, Nigro P (1997) Risk-based capital, portfolio risk and bank capital: a simultaneous equations approach. J Econ Bus 49:533-547 
Jan A, Marimuthu M (2015) Altman model and bankruptcy profile of Islamic banking industry: A comparative analysis on financial performance. Int $\mathrm{J}$ Bus Manag 10:110

Jokipii T, Milne A (2008) The cyclical behaviour of European bank capital buffers. J Bank Financ 32:1440-1451

Jokipii T, Milne A (2011) Bank capital buffer and risk adjustment decisions. J Financ Stab 7:165-178

Kalyvas AN, Mamatzakis E (2014) Does business regulation matter for banks in the European Union? J Int Financ Market Instut Money 32:278-324

Kim D, Santomero AM (1988) Risk in banking and capital regulation. J Financ 43:1219-1233

Kremer S, Bick A, Nautz D (2013) Inflation and growth: new evidence from a dynamic panel threshold analysis. Empir Econ 44:861-878

Krug S, Lengnick M, Wohltmann HW (2015) The impact of Basel III on financial (in) stability: an agent-based credit network approach. Quant Financ 15:1917-1932

Lepetit L, Strobel F (2015) Bank insolvency risk and Z-score measures: A refinement. Financ Res Lett 13:214-224

Liitkepohl H (2006) 6 Structural Vector Autoregressive Analysis for Cointegrated Variables. Econometric Anal 73

Liu YC, Yang W, Mai SY, Mai CC (2012) Explaining bank efficiency differences between China and Taiwan by meta-frontier cost function. Rev Pac Basin Financ Mark 15:1250024

Lützenkirchen K, Rösch D, Scheule H (2014) Asset portfolio securitizations and cyclicality of regulatory capital, Eur J Oper Res 237:289-302

Love I, Zicchino L (2006) Financial development and dynamic investment behavior: Evidence from panel VAR. Quant Rev Econ Financ 46:190-210.

Mamatzakis E and M Tsionas (2019) 'Further Results on Estimating Inefficiency Effects in Stochastic Frontier Models', with Mike G. Tsionas, European Journal of Operational Research, Volume 275, Issue 3, 16 June, Pages 1157-1164.

Mamatzakis E and A. Vu (2018). 'The interplay between Quantitative Easing, Risk and Competition: The case of Japanese banking,' Financial Markets, Institutions \& Instruments Journal, Vu, Volume 27, Issue1, February, Pages 3-46.

Mamatzakis E and M Tsionas (2017). 'Adjustment costs in technical efficiency: an application to global banking.' European Journal of Operational Research, available online 23 June, 256 (2), 640-649.

Mamatzakis E and A Kalyvas (2017) 'Do Creditor Rights and Information Sharing Affect the Performance of Foreign Banks?' Journal of International Financial Markets, Institutions \& Money, Volume 50, September, Pages 13-35.

Mamatzakis E and M. Psillaki (2017). 'What drives bank performance in transitions economies? The impact of reforms and regulations', Research in International Business and Finance, 39, 578-594.

Mamatzakis E and Bermpei (2016). 'What is the effect of unconventional monetary policy on bank performance?' with Theodora Bermpei, Journal of International Money and Finance, 67, 239-263.

Mamatzakis, Emmanuel, Matousek, Roman and Vu, Anh Nguyet (2016) What is the impact of problem loans on Japanese bank productivity growth? In: PortsmouthFordham Conference on Banking and Finance, 24-25 September 2016, Portsmouth Business School. 
Mamatzakis E (2015). Risk and efficiency in the Central and Eastern European banking industry under quantile analysis. Quant Financ 15:553-567.

Mamatzakis E and M Tsionas (2015). 'How are market preferences shaped? The case of sovereign debt of stressed euro-area countries', Journal of Banking \& Finance 61, 106-116.

Mamatzakis E with MG Tsionas, SC Kumbhakar, A Koutsomanoli-Filippaki (2015). 'Does labour regulation affect technical and allocative efficiency? Evidence from the banking industry', 61, Journal of Banking \& Finance.

Mamatzakis E, Bermpei T (2014). What drives investment bank performance? The role of risk, liquidity and fees prior to and during the crisis. Int Rev Financ Anal 35:102-117.

Mamatzakis E. and Koutsomanoli-Filippaki, Anastasia, (2009). 'Performance and Merton-type default risk of listed banks in the EU: A panel VAR approach,' Journal of Banking \& Finance, Elsevier, vol. 33(11), pages 2050-2061, November, 2009

Mare DS, Moreira F Rossi R (2016) Nonstationary Z-Score measures, Eur J Oper Res.

Myers SC, Majluf NS (1984) Corporate financing and investment decisions when firms have information that investors do not have. J Financ Econ 13:187-221

Nickell S (1981) Biases in Dynamic Models with Fixed Effects. Econometrica 49:14171426

Nicoló GD, Bartholomew P, Zaman J, Zephirin M (2004) Bank Consolidation, Internationalization, and Conglomeration: Trends and Implications for Financial Risk. Financ Market Inst Instrum 13:173-217

Nier E, Baumann U (2006) Market discipline, disclosure and moral hazard in banking. J Financ Intermed 15:332-361

Oral M, Yolalan R (1990) An empirical study on measuring operating efficiency and profitability of bank branches. Eur J Oper Res 46:282-294

Pasiouras F (2008) International evidence on the impact of regulations and supervision on banks' technical efficiency: an application of two-stage data envelopment analysis. Rev Quant Financ Acc 30:187-223

Pasiouras F, Gaganis C, Zopounidis C (2006) The impact of bank regulations, supervision, market structure, and bank characteristics on individual bank ratings: A cross-country analysis. Rev Quant Financ Acc 27:403-438

Repullo R, Suarez J (2012) The procyclical effects of bank capital regulation. Rev Financ Stud 26:452-490

Radić N, Fiordelisi F, Girardone C (2012) Efficiency and risk-taking in pre-crisis investment banks. J Financ Serv Res 41:81-101

Rime B (2001) Capital requirements and bank behaviour: Empirical evidence for Switzerland. J Bank Financ 25:789-805

Sealey CW, Lindley JT (1977) Inputs, outputs, and a theory of production and cost at depository financial institutions. J Financ 32:1251-1266

Sharma N (2013) Altman model and financial soundness of Indian banks. Int J Acc Financ Manag Res 3:60

Sharma P, Gounder N, Xiang D (2015) Level and determinants of foreign bank efficiency in a pacific island country. Rev Pac Basin Financ Mark 18:1550005

Shim J (2013) Bank capital buffer and portfolio risk: The influence of business cycle and revenue diversification. J Bank Financ 37:761-772 
Shrieves RE, Dahl D (1992) The relationship between risk and capital in commercial banks. J Bank Financ 16:439-457

Soedarmono W, Machrouh F, Tarazi A (2013) Bank competition, crisis and risk taking: Evidence from emerging markets in Asia. J Int Financ Market Instut Money 23:196-221

Stiroh KJ, Rumble A (2006) The dark side of diversification: The case of US financial holding companies. J Bank Financ 30:2131-2161

Stolz S, Wedow M (2011) Banks' regulatory capital buffer and the business cycle: Evidence for Germany. J Financ Stab 7:98-110

Tzeremes NG, (2015) Efficiency dynamics in Indian banking: A conditional directional distance approach, Eur J Oper Res 240:807-818

Windmeijer F (2005) A finite sample correction for the variance of linear efficient twostep GMM estimators. J Econometrics 126:25-51 
Appendix

Table I: Variable definitions and data sources.

\begin{tabular}{|c|c|c|}
\hline Variables & Definition & Source \\
\hline \multicolumn{3}{|l|}{$\begin{array}{l}\text { Bank-specific } \\
\text { variables }\end{array}$} \\
\hline Buffer (BUFF) & $\begin{array}{l}\text { The amount of capital banks hold in excess of the } \\
\text { minimum requirement and iscalculated as } \\
\text { regulatory capital (Tier } 1 \text { plus Tier } 2 \text { over Risk } \\
\text { Weighted Assets) minus minimum capital } \\
\text { requirement. }\end{array}$ & BankScope \\
\hline $\begin{array}{l}\text { Cost Efficiency } \\
\text { (EFF) }\end{array}$ & $\begin{array}{l}\text { A measure of bank performance. This variable } \\
\text { indicates how close a firm's profits are to the } \\
\text { benchmark of the best practice firm. The measure } \\
\text { of EFF is given by the ratio of minimum cost to } \\
\text { actual cost and is bounded between zero and } \\
\text { unity. We employ Stochastic Frontier Analysis in } \\
\text { order to estimate cost efficiency for each bank. }\end{array}$ & SFA \\
\hline ROE & $\begin{array}{l}\text { Return on equity. This variable is defined as the } \\
\text { ratio of net profits over equity }(\%) \text {. }\end{array}$ & BankScope \\
\hline ROA & $\begin{array}{l}\text { Return on assets. This variable is defined as the } \\
\text { ratio of net profits over total assets }(\%) \text {. }\end{array}$ & BankScope \\
\hline NIM & $\begin{array}{l}\text { Net interest margin. This variable is defined as the } \\
\text { ratio of net interest income over total assets. }\end{array}$ & BankScope \\
\hline $\begin{array}{l}\text { Non-performing } \\
\text { loans (NPL) }\end{array}$ & $\begin{array}{l}\text { The ratio of non-performing loans over total } \\
\text { loans. }\end{array}$ & BankScope \\
\hline $\begin{array}{l}\text { Risk-Weighted } \\
\text { Assets (RWA) }\end{array}$ & $\begin{array}{l}\text { The ratio of bank risk-weighted assets over total } \\
\text { assets. }\end{array}$ & BankScope \\
\hline $\begin{array}{l}\text { Off-Balance- } \\
\text { Sheet items } \\
\text { (OBS) }\end{array}$ & $\begin{array}{l}\text { Measured as the non-interest income and fee } \\
\text { generating services from various contingent } \\
\text { liabilities such as letters of credit, derivatives, } \\
\text { securities underwriting, insurance and other types } \\
\text { of non-traditional banking activities. }\end{array}$ & BankScope \\
\hline $\begin{array}{l}\text { Altman's Z-Score } \\
\text { (ALTMANZ) }\end{array}$ & $\begin{array}{l}\text { Altman's Z-Score shows bank likelihood of } \\
\text { bankruptcy and is calculated based on the } \\
\text { following formula: ALTMANZ }=1.2 X_{1}+ \\
1.4 X_{2}+3.3 X_{3}+0.64 X_{5}+0.999 X_{5} \text {. }\end{array}$ & \\
\hline $\begin{array}{l}\text { Z-Score (Z- } \\
\text { SCORE) }\end{array}$ & $\begin{array}{l}\text { Z-Score indicates the risk of failure for a bank and } \\
\text { is measured according to the following formula: } \\
\text { Z-Score }=(1+\mathrm{ROE}) / \text { Standard Deviation of } \\
\text { ROE and indicates the probability of failure for a } \\
\text { given bank. }\end{array}$ & BankScope \\
\hline Bank size (SIZE) & $\begin{array}{l}\text { The natural log of total assets is used as a measure } \\
\text { of bank size. }\end{array}$ & BankScope \\
\hline $\begin{array}{l}\text { Disclosure } \\
\text { (DISCLSR) }\end{array}$ & $\begin{array}{l}\text { A dummy variable that takes the value } 1 \text { for listed } \\
\text { banks and } 0 \text { unlisted indicating information } \\
\text { disclosure. }\end{array}$ & BankScope \\
\hline $\begin{array}{l}\text { Commercial } \\
\text { banks (COM) }\end{array}$ & $\begin{array}{l}\text { A Dummy taking the value } 1 \text { for commercial } \\
\text { banks and } 0 \text { for saving banks. }\end{array}$ & BankScope \\
\hline $\begin{array}{l}\text { Country-specific } \\
\text { variables }\end{array}$ & & \\
\hline
\end{tabular}




\begin{tabular}{lll}
\hline $\begin{array}{l}\text { GDP growth } \\
\text { (GDPGR) }\end{array}$ & GDP growth of each country. & $\begin{array}{l}\text { World } \\
\text { Development } \\
\text { Indicators } \\
\text { (WDI) }\end{array}$ \\
$\begin{array}{l}\text { Concentration } \\
\text { ratio (C5) }\end{array}$ & $\begin{array}{l}\text { The concentration ratio (C5) in the banking } \\
\text { industry measured by the sum of the assets of the } \\
\text { five largest banks as anare of all banks in each } \\
\text { country and for each year. }\end{array}$ \\
$\begin{array}{l}\text { European } \\
\begin{array}{l}\text { Donetary Union variable that takes the value 1 for } \\
\text { countries (EMU) }\end{array}\end{array}$ & $\begin{array}{l}\text { European Monetary Union countries and } 0 \\
\text { otherwise. }\end{array}$ \\
\hline
\end{tabular}


List of tables

Table 1: Total regulatory capital across country for EU-27 (2004 - 2013)

Total regulatory capital across country for EU-27, (2004 - 2013).

\begin{tabular}{lccclccc}
\hline Country & Mean & Max & Min & Country & Mean & Max & Min \\
\hline AUSTRIA & 25.97 & 190 & 9.19 & LATVIA & 16.11 & 80.29 & 8.02 \\
BELGIUM & 16.5 & 43.81 & 8.87 & LITHUANIA & 14.1 & 29.6 & 8.95 \\
BULGARIA & 16.23 & 40.15 & 10.2 & LUXEMBOURG & 21.65 & 111.7 & 8.68 \\
CROATIA & 17.59 & 38.67 & 9.17 & MALTA & 16.24 & 44.86 & 8.06 \\
CYPRUS & 14.27 & 47.34 & 8.2 & NETHERLANDS & 16.48 & 45.9 & 9.3 \\
CZECH REPUBLIC & 18.08 & 108.15 & 9.11 & POLAND & 13.84 & 33.64 & 8.63 \\
DENMARK & 17.77 & 132.3 & 8.3 & PORTUGAL & 14.97 & 79.8 & 8.4 \\
ESTONIA & 19.58 & 32.5 & 10.54 & ROMANIA & 18.41 & 122.63 & 9.77 \\
FINLAND & 16.79 & 26.75 & 10.6 & SLOVAKIA & 15.31 & 30.38 & 9.05 \\
FRANCE & 12.79 & 57 & 8.87 & SLOVENIA & 13.49 & 51.3 & 8.06 \\
GERMANY & 18 & 95.7 & 8.1 & SPAIN & 15.88 & 71.9 & 8.17 \\
GREECE & 13.74 & 36.6 & 8.51 & SWEDEN & 18.16 & 44.96 & 1.04 \\
HUNGARY & 13.05 & 22.13 & 8.89 & UNITED KINGDOM & 18.07 & 102.9 & 9.7 \\
IRELAND & 12.83 & 25 & 8.3 & Mean & 17.17 & 190 & 1.04 \\
ITALY & 15.95 & 187 & 7.8 & & & & \\
\hline
\end{tabular}

Note: The table reports the mean total regulatory capital for EU-27 countries. The total regulatory capital is calculated as the sum of Tier 1 and Tier 2 capital over Risk Weighted Assets.

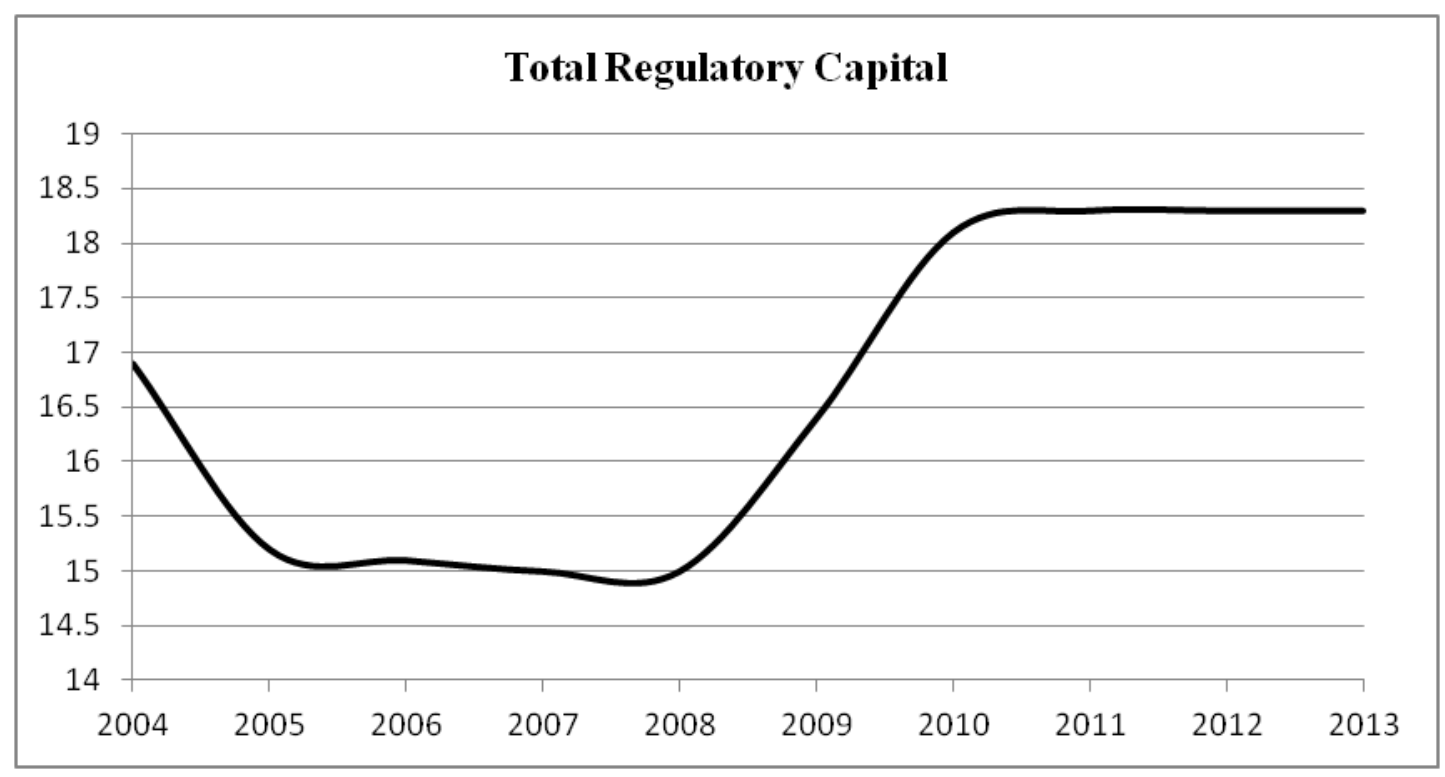

Figure 1: Mean total regulatory capital for EU-27 countries over the years 2004-2013. The total regulatory capital is calculated as the sum of Tier 1 and Tier 2 capital over Risk Weighted Assets. 
Table 2: National total regulatory capital requirements

\begin{tabular}{lcc}
\hline & $\begin{array}{c}\text { Minimum capital } \\
\text { requirement }\end{array}$ & $\begin{array}{c}\text { Year of } \\
\text { Implementation }\end{array}$ \\
\hline UK & $9 \%$ & 1979 \\
Cyprus & $8 \%$ & 1997 \\
& $10 \%$ & 2001 \\
Estonia & $10 \%$ & 1997 \\
Latvia & $10 \%$ & 1997 \\
& $8 \%$ & 2004 \\
Lithuania & $10 \%$ & 1997 \\
& $8 \%$ & 2005 \\
\hline
\end{tabular}

Note: The table shows the minimum capital requirements for countries that had set different minimum ratio over time. The minimum capital requirements for all other EU-27 countries is calculated with $8 \%$ of Risk Weighted Assets according to Jokipii and Milne (2008).

Table 3: Bank capital buffer across country for EU-27 (2004 - 2013)

\begin{tabular}{|c|c|c|c|c|c|c|c|}
\hline Country & Mean & Max & Min & Country & Mean & $\operatorname{Max}$ & Min \\
\hline AUSTRIA & 14.59 & 15.7 & 13.12 & LATVIA & 11.53 & 16.54 & 4.79 \\
\hline BELGIUM & 15.35 & 17.25 & 13.01 & LITHUANIA & 11.91 & 16.54 & 7.35 \\
\hline BULGARIA & 11.28 & 17.02 & 8.44 & LUXEMBOURG & 13.82 & 15.22 & 11.5 \\
\hline CROATIA & 10.92 & 14.11 & 6.09 & MALTA & 11.3 & 12.91 & 10.4 \\
\hline CYPRUS & 11.03 & 14.43 & 6.23 & NETHERLANDS & 13.05 & 17.02 & 10.9 \\
\hline $\begin{array}{l}\text { CZECH } \\
\text { REPUBLIC }\end{array}$ & 12.34 & 12 & 9.03 & PO & 12.48 & 15.35 & 9.66 \\
\hline DENMARK & 11.41 & 16.54 & 7.72 & PORTUGAL & 14.54 & 17.72 & 9.22 \\
\hline ESTONIA & 12.28 & 14.06 & 8.8 & ROMANIA & 11.68 & 13.95 & 8.73 \\
\hline FINLAND & 13.4 & 15.88 & 10.53 & SLOVAKIA & 11.57 & 13.62 & 9.63 \\
\hline FRANCE & 14.45 & 17.53 & 11.18 & SLOVENIA & 11.07 & 13.24 & 8.81 \\
\hline GERMANY & 10.89 & 17.25 & 6.34 & SPAIN & 13.67 & 16.44 & 9.46 \\
\hline GREECE & 12.42 & 15.17 & 9.01 & SWEDEN & 10.98 & 15.35 & 6.29 \\
\hline HUNGARY & 12.56 & 14.92 & 8.36 & $\begin{array}{l}\text { UNITED } \\
\text { KINGDOM }\end{array}$ & 13.92 & 17.72 & 9.06 \\
\hline IRELAND & 14.01 & 17.53 & 9.82 & Mean & 11.75 & 17.72 & 4.61 \\
\hline ITALY & 11.12 & 17.13 & 4.61 & & & & \\
\hline
\end{tabular}

Note: The table reports the mean bank capital buffer for EU-27 countries. The bank capital buffer is calculated as the natural logarithm of total regulatory capital minus minimum capital requirement, where total regulatory capital is the sum of Tier 1 plus Tier 2 over Risk Weighted Assets. 


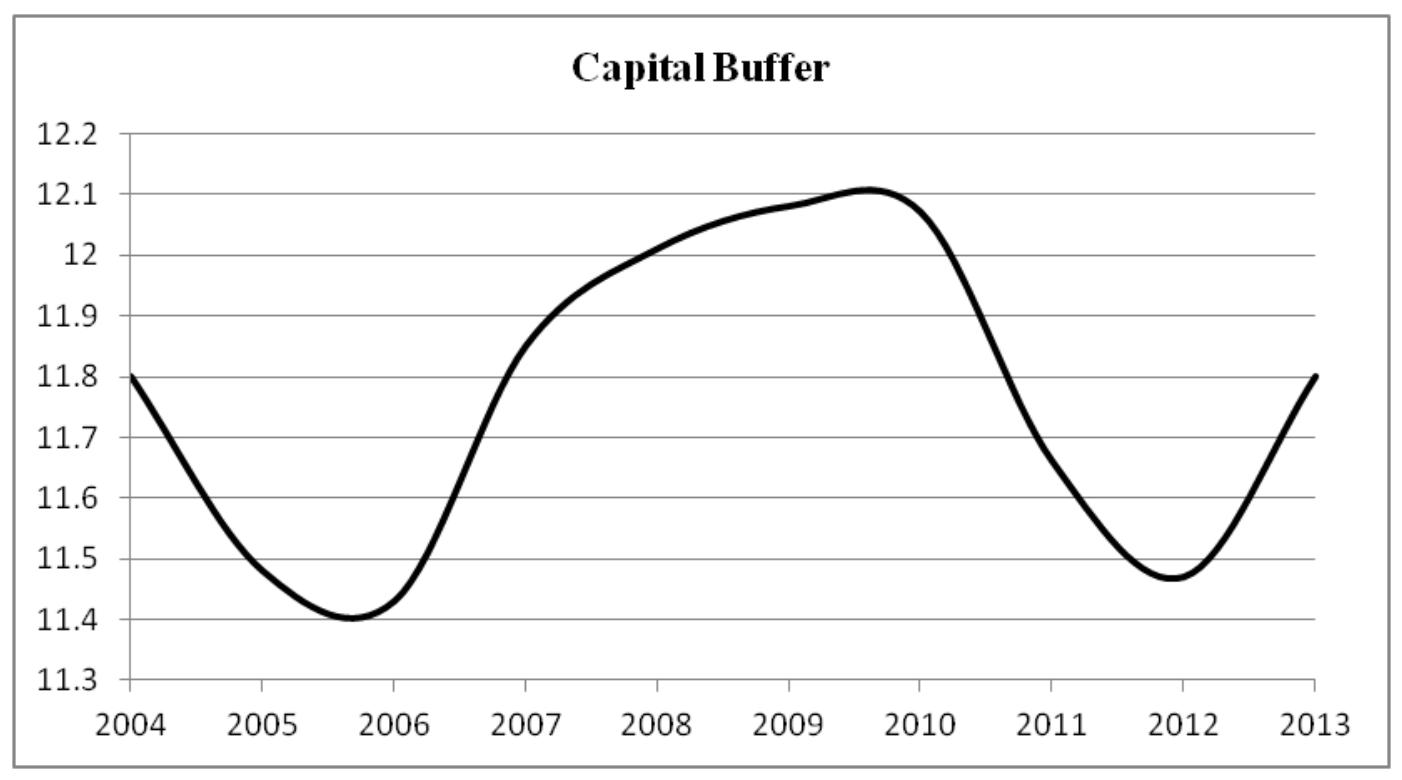

Figure 2: Mean capital buffer for EU-27 countries over the years 2004-2013. The bank capital buffer is calculated as the natural logarithm of total regulatory capital minus minimum capital requirement, where total regulatory capital is the sum of Tier 1 plus Tier 2 over Risk Weighted Assets.

Table 4: Bank cost efficiency estimates across country for EU-27 (2004 - 2013)

Bank cost efficiency estimates across country for EU-27, (2004 - 2013).

\begin{tabular}{lccclccc}
\hline Country & Mean & Max & Min & Country & Mean & Max & Min \\
\hline AUSTRIA & 0.78 & 0.88 & 0.7 & LATVIA & 0.77 & 0.94 & 0.59 \\
BELGIUM & 0.7 & 0.86 & 0.4 & LITHUANIA & 0.76 & 0.87 & 0.55 \\
BULGARIA & 0.64 & 0.82 & 0.42 & LUXEMBOURG & 0.72 & 0.84 & 0.52 \\
CROATIA & 0.66 & 0.79 & 0.48 & MALTA & 0.85 & 0.92 & 0.78 \\
CYPRUS & 0.76 & 0.93 & 0.44 & NETHERLANDS & 0.73 & 0.86 & 0.5 \\
CZECH & 0.8 & 0.95 & 0.57 & POLAND & 0.73 & 0.9 & 0.52 \\
REPUBLIC & 0.8 & 0.9 & 0.61 & PORTUGAL & 0.72 & 0.89 & 0.43 \\
DENMARK & 0.78 & 0.94 & 0.55 & ROMANIA & 0.63 & 0.78 & 0.46 \\
ESTONIA & 0.79 & 0.95 & 0.48 & SLOVAKIA & 0.78 & 0.86 & 0.57 \\
FINLAND & 0.76 & 0.92 & 0.42 & SLOVENIA & 0.78 & 0.88 & 0.57 \\
FRANCE & 0.8 & 0.89 & 0.29 & SPAIN & 0.84 & 0.97 & 0.43 \\
GERMANY & 0.75 & 0.91 & 0.52 & SWEDEN & 0.83 & 0.98 & 0.46 \\
GREECE & 0.63 & 0.75 & 0.45 & UNITED & 0.79 & 0.96 & 0.47 \\
HUNGARY & 0.79 & 0.91 & 0.62 & Mean & 0.78 & 0.98 & 0.29 \\
IRELAND & 0.82 & 0.95 & 0.48 & & & & \\
ITALY & & & & & & & \\
\hline
\end{tabular}

Note: The table reports the mean cost efficiency for EU-27 countries. The bank cost efficiency scores are estimated employing Stochastic Frontier Analysis (SFA). 


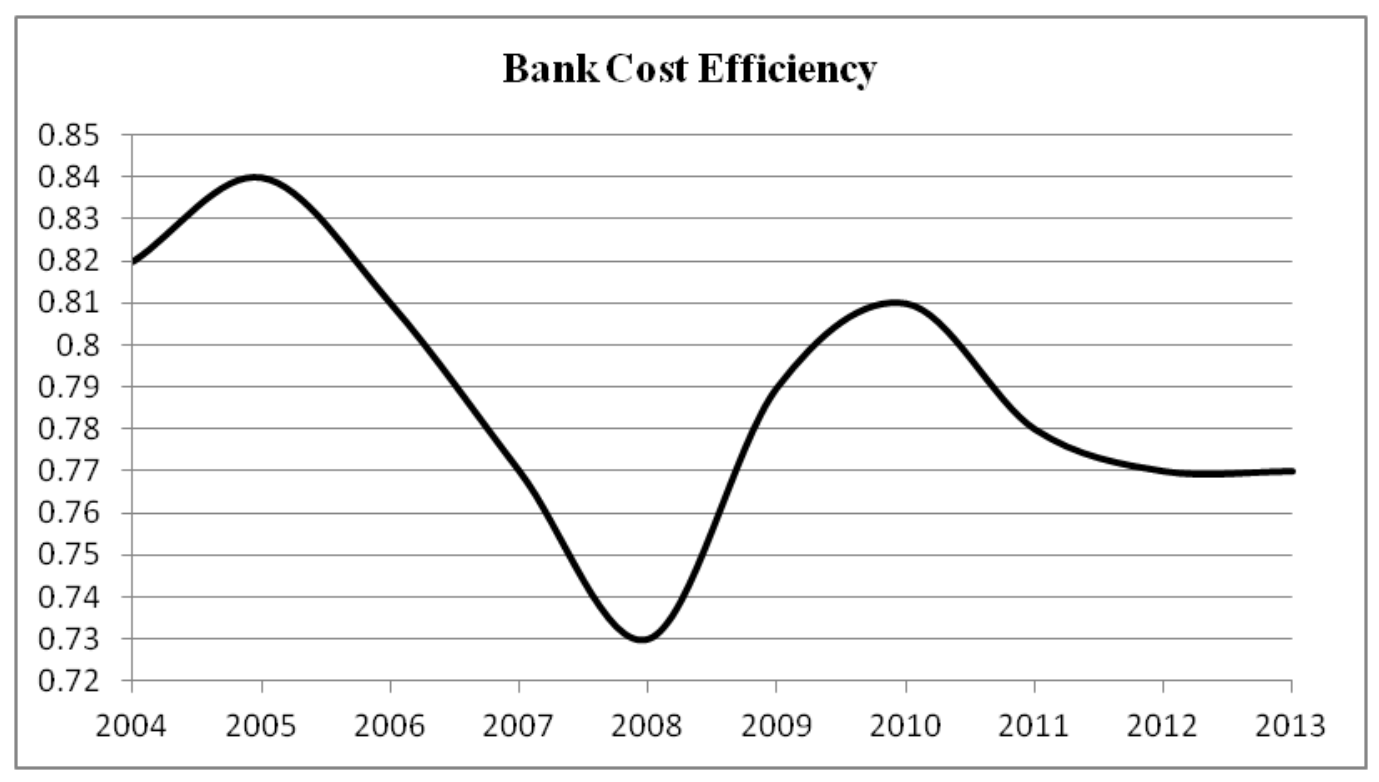

Figure 3: Bank cost efficiency estimates over the years 2004-2013. The bank cost efficiency scores are estimated employing Stochastic Frontier Analysis (SFA).

Table 5: Descriptive statistics for variables

\begin{tabular}{lcccc}
\hline Variable & Mean & Std. Dev. & Min & Max \\
\hline BUFF & 11.75 & 2.14 & 4.61 & 17.72 \\
EFF & 0.78 & 0.09 & 0.29 & 0.98 \\
ROE & 4.27 & 21.36 & -135 & 146 \\
ROA & 0.39 & 1.70 & -29.86 & 77.81 \\
NIM & 2.57 & 1.79 & -36.27 & 34.689 \\
NPL & 0.06 & 0.8 & -0.04 & 0.92 \\
RWA & 5.46 & 0.87 & 0.002 & 40 \\
OBS & 0.15 & 0.49 & -0.04 & 19.72 \\
ALTMANZ & 7.16 & 16.86 & -1.25 & 50 \\
ZSCORE & 2.49 & 4.44 & -4.56 & 55.07 \\
SIZE & 15.13 & 2.36 & 9.40 & 21.51 \\
GDPGR & 0.65 & 3.21 & -17.95 & 12.23 \\
C5 & 0.82 & 0.10 & 0.49 & 1 \\
\hline
\end{tabular}

Note: BUFF is the capital buffer calculated as the regulatory capital (Tier 1 plus Tier 2 over Risk Weighted Assets) minus minimum capital requirement. EFF stands for performance measure and is derived from SFA. ROE, ROA and NIM stand for additional bank performance measures and are the ratios of return on equity, return on assets and net interest margin respectively. NPL stands for the ratio of non-performing loans over total loans, RWA is calculated as the ratio of risk-weighted assets over total assets, OBS stands for the Off-Balance-Sheet items measured as the ratio of Off-Balance-Sheet items over total liabilities, ALTMANZ stands for Altman's Z-Score: AZSCORE $=1.2 X_{1}+1.4 X_{2}+$ $3.3 X_{3}+0.64 X_{5}+0.999 X_{5}$ and ZSCORE presents bank's distance from default calculated from the formula: ZSCORE $=(1+\mathrm{ROE}) /$ Standard Deviation of ROE. SIZE is the log of total assets and measures the bank size. GDPGR stands for the GDP growth, while C5 stands for the five-firm concentration ratio of each country's banking industry. 
Table 6: Dynamic Panel results for bank capital buffer using efficiency as performance measure (2004 - 2013)

\begin{tabular}{|c|c|c|c|c|c|c|c|c|}
\hline VARIABLES & Model (1) & Model (2) & Model (3) & Model (4) & Model (5) & Model (6) & Model (7) & Model (8) \\
\hline L.BFF & $\begin{array}{c}0.812 * * * \\
(0.048)\end{array}$ & $\begin{array}{c}0.756 * * * \\
(0.066)\end{array}$ & $\begin{array}{c}0.440 * * * \\
(0.078)\end{array}$ & $\begin{array}{c}0.561 * * * \\
(0.058)\end{array}$ & $\begin{array}{c}0.410 * * * \\
(0.066)\end{array}$ & $\begin{array}{c}0.580 * * * \\
(0.054)\end{array}$ & $\begin{array}{c}0.518 * * * \\
(0.060)\end{array}$ & $\begin{array}{c}0.428 * * * \\
(0.060)\end{array}$ \\
\hline EFF & & $\begin{array}{c}4.105 * * * \\
(1.491)\end{array}$ & $\begin{array}{c}1.967 * * \\
(0.951)\end{array}$ & $\begin{array}{c}1.425 * * \\
(0.573)\end{array}$ & $\begin{array}{c}1.778 * * \\
(0.879)\end{array}$ & $\begin{array}{c}0.896 \\
(0.743)\end{array}$ & $\begin{array}{c}1.641 * * * \\
(0.602)\end{array}$ & $\begin{array}{c}0.530 * * \\
(0.298)\end{array}$ \\
\hline ALTMANZ & & & $\begin{array}{c}0.057 * * \\
(0.026)\end{array}$ & & & & & $\begin{array}{c}0.045 * * * \\
(0.015)\end{array}$ \\
\hline ZSCORE & & & & $\begin{array}{c}0.005 \\
(0.019)\end{array}$ & & & & \\
\hline NPL & & & & & $\begin{array}{c}0.003 \\
(0.004)\end{array}$ & & & $\begin{array}{c}0.003 \\
(0.003)\end{array}$ \\
\hline OBS & & & & & & $\begin{array}{l}0.063 * \\
(0.035)\end{array}$ & & $\begin{array}{l}0.031^{*} \\
(0.017)\end{array}$ \\
\hline RWA & & & & & & & $\begin{array}{c}0.331 \\
(0.221)\end{array}$ & $\begin{array}{c}0.094 \\
(0.112)\end{array}$ \\
\hline DISCLOSURE & & & $\begin{array}{c}0.146 \\
(0.509)\end{array}$ & $\begin{array}{l}-0.044 \\
(0.293)\end{array}$ & $\begin{array}{c}0.246 \\
(0.336)\end{array}$ & $\begin{array}{c}0.221 \\
(0.262)\end{array}$ & $\begin{array}{c}-0.542 \\
(0.397)\end{array}$ & $\begin{array}{c}0.196 \\
(0.149)\end{array}$ \\
\hline SIZE & & & $\begin{array}{c}0.507 * * * \\
(0.105)\end{array}$ & $\begin{array}{c}0.401 * * * \\
(0.066)\end{array}$ & $\begin{array}{c}0.562 * * * \\
(0.077)\end{array}$ & $\begin{array}{c}0.343 * * * \\
(0.063)\end{array}$ & $\begin{array}{c}0.442 * * * \\
(0.075)\end{array}$ & $\begin{array}{c}0.562 * * * \\
(0.061)\end{array}$ \\
\hline $\mathrm{COM}$ & & & $\begin{array}{c}0.042 \\
(0.141)\end{array}$ & $\begin{array}{c}0.062 \\
(0.063)\end{array}$ & $\begin{array}{l}-0.082 \\
(0.122)\end{array}$ & $\begin{array}{c}0.038 \\
(0.099)\end{array}$ & $\begin{array}{c}0.246^{* *} \\
(0.101)\end{array}$ & $\begin{array}{c}0.248 * * \\
(0.111)\end{array}$ \\
\hline $\mathrm{C} 5$ & & & $\begin{array}{l}-0.210 \\
(0.279)\end{array}$ & $\begin{array}{c}0.135 \\
(0.194)\end{array}$ & $\begin{array}{c}0.007 \\
(0.242)\end{array}$ & $\begin{array}{c}0.085 \\
(0.171)\end{array}$ & $\begin{array}{c}0.149 \\
(0.232)\end{array}$ & $\begin{array}{l}-0.076 \\
(0.211)\end{array}$ \\
\hline GDPGR & & & $\begin{array}{c}0.002 \\
(0.007)\end{array}$ & $\begin{array}{c}0.002 \\
(0.008)\end{array}$ & $\begin{array}{l}-0.001 \\
(0.007)\end{array}$ & $\begin{array}{c}0.010 \\
(0.006)\end{array}$ & $\begin{array}{c}0.003 \\
(0.007)\end{array}$ & $\begin{array}{c}0.011 \\
(0.005)\end{array}$ \\
\hline EMU & & & $\begin{array}{c}-0.129 \\
(0.114)\end{array}$ & $\begin{array}{c}-0.217 * * * \\
(0.076)\end{array}$ & $\begin{array}{c}-0.249 * * * \\
(0.079)\end{array}$ & $\begin{array}{c}-0.120 * * \\
(0.048)\end{array}$ & $\begin{array}{c}-0.274 * * * \\
(0.094)\end{array}$ & $\begin{array}{c}-0.145^{* *} \\
(0.042)\end{array}$ \\
\hline Constant & $2.112 * * *$ & -0.132 & $-2.631 * * *$ & $-1.842 * * *$ & $-2.693 * * *$ & $-1.111^{*}$ & $-1.529 * * *$ & $-2.395 * * *$ \\
\hline
\end{tabular}




\begin{tabular}{|c|c|c|c|c|c|c|c|c|}
\hline VARIABLES & Model (1) & Model (2) & Model (3) & Model (4) & Model (5) & Model (6) & Model (7) & Model (8) \\
\hline & $(0.510)$ & (1.016) & (1.019) & (0.697) & (0.909) & (0.649) & $(0.452)$ & $(0.514)$ \\
\hline Time Dummies & YES & YES & YES & YES & YES & YES & YES & YES \\
\hline Hansen test & 0.0107 & 0.0812 & 0.411 & 0.0701 & 0.384 & 0.270 & 0.380 & 0.072 \\
\hline $\mathrm{AR}(2)$ & 1.836 & 1.551 & 1.774 & 1.717 & 1.365 & 1.402 & 1.671 & 1.187 \\
\hline
\end{tabular}

Note: The table reports the dynamic panel regression results. The two-step GMM (Arellano and Bover, 1995) is used with Windmeijer corrected (robust) errors. We consider as exogenous the country-specific and time dummy variables and as endogenous the bank-specific variables. The instruments chosen for the lagged endogenous variables are two-to-six period lags. AR (2) stands for the p-value of the second order residual autocorrelation tests. Hansen test stands for the p-value of Hansen's J diagnostic test for instrument validity. The dependent variable is the capital buffer (BUFF) calculated as the regulatory capital (Tier 1 plus Tier 2 over Risk Weighted Assets) minus minimum capital requirement. L.BUFF is the lagged value of the dependent variable BUFF representing the dynamic nature of the model. EFF stands or the cost efficiency scores calculated using SFA methodology. ALTMANZ presents Altman's Z-Score and is a measure of bank likelihood for default. ZSCORE presents bank's distance from default calculated from the formula: ZSCORE $=(1+$ ROE $) /$ Standard Deviation of ROE. NPL stands for the ratio of non-performing loan over total loans, OBS stands for the Off-BalanceSheet items measured as the ratio of Off-Balance-Sheet items over total liabilities. RWA stands for the bank risk exposure and is calculated as the ratio of risk-weighted assets over total assets, DISCLSR is a dummy taking the value 1 for listed banks and 0 unlisted and stands as a second measure of market discipline indicating information disclosure. SIZE is the log of total assets and measures the bank size while C5 stands for the five-firm concentration ratio of each country's banking industry. GDPGR stands for the GDP growth, EMU is a dummy taking the value 1 for banks in Eurozone and 0 otherwise and COM is a dummy taking the value 1 for commercial banks and 0 for saving banks.

***, ** and * indicate $1 \%, 5 \%$ and $10 \%$ significance levels respectively. 
Table 7: Dynamic Panel results for bank capital buffer using different performance measures (2004 - 2013)

\begin{tabular}{|c|c|c|c|c|c|c|c|}
\hline VARIABLES & Model (1) & Model (2) & Model (3) & Model (4) & Model (5) & Model (6) & Model (7) \\
\hline L.BFF & $\begin{array}{c}0.404 * * * \\
(0.054)\end{array}$ & $\begin{array}{c}0.428 * * * \\
(0.059)\end{array}$ & $\begin{array}{c}0.422 * * * \\
(0.060)\end{array}$ & $\begin{array}{c}0.406 * * * \\
(0.059)\end{array}$ & $\begin{array}{c}0.420 * * * \\
(0.055)\end{array}$ & $\begin{array}{c}0.422 * * * \\
(0.055)\end{array}$ & $\begin{array}{c}0.394 * * * \\
(0.055)\end{array}$ \\
\hline $\mathrm{EFF}$ & $\begin{array}{c}0.699 * * \\
(0.277)\end{array}$ & & & & $\begin{array}{c}0.598^{* *} \\
(0.287)\end{array}$ & $\begin{array}{c}0.751 * * * \\
(0.285)\end{array}$ & $\begin{array}{c}0.901 * * * \\
(0.322)\end{array}$ \\
\hline ROE & & $\begin{array}{c}0.003 * * * \\
(0.001)\end{array}$ & & & $\begin{array}{c}0.003 * * * \\
(0.001)\end{array}$ & & \\
\hline ROA & & & $\begin{array}{c}0.050 \\
(0.031)\end{array}$ & & & $\begin{array}{c}0.060 * * \\
(0.027)\end{array}$ & \\
\hline NIM & & & & $\begin{array}{l}0.050^{*} \\
(0.028)\end{array}$ & & & $\begin{array}{c}0.090^{* * * *} \\
(0.029)\end{array}$ \\
\hline ALTMANZ & $\begin{array}{c}0.051 * * * \\
(0.014)\end{array}$ & $\begin{array}{c}0.050 * * * \\
(0.015)\end{array}$ & $\begin{array}{c}0.052 * * * \\
(0.018)\end{array}$ & $\begin{array}{c}0.055^{*} * * \\
(0.017)\end{array}$ & $\begin{array}{c}0.048 * * * \\
(0.013)\end{array}$ & $\begin{array}{c}0.046 * * * \\
(0.015)\end{array}$ & $\begin{array}{c}0.051 * * * \\
(0.014)\end{array}$ \\
\hline NPL & $\begin{array}{c}0.006 \\
(0.005)\end{array}$ & $\begin{array}{c}0.004 \\
(0.005)\end{array}$ & $\begin{array}{c}0.004 \\
(0.005)\end{array}$ & $\begin{array}{l}-0.001 \\
(0.004)\end{array}$ & $\begin{array}{l}0.008 * \\
(0.005)\end{array}$ & $\begin{array}{l}0.009^{*} \\
(0.005)\end{array}$ & $\begin{array}{c}0.001 \\
(0.004)\end{array}$ \\
\hline OBS & $\begin{array}{c}0.047 * * \\
(0.019)\end{array}$ & $\begin{array}{c}0.024 \\
(0.017)\end{array}$ & $\begin{array}{c}0.022 \\
(0.017)\end{array}$ & $\begin{array}{c}0.034 * * \\
(0.017)\end{array}$ & $\begin{array}{l}0.038^{*} \\
(0.020)\end{array}$ & $\begin{array}{l}0.037^{*} \\
(0.020)\end{array}$ & $\begin{array}{c}0.051 * * \\
(0.020)\end{array}$ \\
\hline RWA & $\begin{array}{c}0.065 \\
(0.121)\end{array}$ & $\begin{array}{c}0.115 \\
(0.150)\end{array}$ & $\begin{array}{c}0.059 \\
(0.176)\end{array}$ & $\begin{array}{c}0.020 \\
(0.078)\end{array}$ & $\begin{array}{c}0.077 \\
(0.122)\end{array}$ & $\begin{array}{c}0.077 \\
(0.164)\end{array}$ & $\begin{array}{l}-0.005 \\
(0.068)\end{array}$ \\
\hline DISCLOSURE & $\begin{array}{c}0.210 \\
(0.154)\end{array}$ & $\begin{array}{c}0.008 \\
(0.164)\end{array}$ & $\begin{array}{c}0.057 \\
(0.164)\end{array}$ & $\begin{array}{c}0.054 \\
(0.156)\end{array}$ & $\begin{array}{c}0.161 \\
(0.148)\end{array}$ & $\begin{array}{c}0.199 \\
(0.159)\end{array}$ & $\begin{array}{c}0.168 \\
(0.146)\end{array}$ \\
\hline SIZE & $\begin{array}{c}0.583 * * * \\
(0.058)\end{array}$ & $\begin{array}{c}0.586 * * * \\
(0.067)\end{array}$ & $\begin{array}{c}0.580 * * * \\
(0.069)\end{array}$ & $\begin{array}{c}0.606 * * * \\
(0.064)\end{array}$ & $\begin{array}{c}0.580 * * * \\
(0.059)\end{array}$ & $\begin{array}{c}0.572 * * * \\
(0.060)\end{array}$ & $\begin{array}{c}0.620 * * * \\
(0.059)\end{array}$ \\
\hline $\mathrm{COM}$ & $\begin{array}{c}-0.289^{* *} \\
(0.115)\end{array}$ & $\begin{array}{c}-0.329 * * \\
(0.137)\end{array}$ & $\begin{array}{l}-0.252^{*} \\
(0.132)\end{array}$ & $\begin{array}{c}-0.282^{*} \\
(0.145)\end{array}$ & $\begin{array}{c}-0.374 * * * \\
(0.122)\end{array}$ & $\begin{array}{c}-0.340^{* * * *} \\
(0.128)\end{array}$ & $\begin{array}{c}-0.344 * * * \\
(0.125)\end{array}$ \\
\hline $\mathrm{C} 5$ & $\begin{array}{l}-0.068 \\
(0.163)\end{array}$ & $\begin{array}{l}-0.033 \\
(0.147)\end{array}$ & $\begin{array}{l}-0.103 \\
(0.153)\end{array}$ & $\begin{array}{l}-0.041 \\
(0.148)\end{array}$ & $\begin{array}{l}-0.028 \\
(0.162)\end{array}$ & $\begin{array}{c}-0.080 \\
(0.170)\end{array}$ & $\begin{array}{l}-0.007 \\
(0.172)\end{array}$ \\
\hline GDPGR & $0.010 *$ & $0.010 *$ & $0.011 *$ & $0.011 * *$ & 0.007 & 0.006 & 0.006 \\
\hline
\end{tabular}




\begin{tabular}{|c|c|c|c|c|c|c|c|}
\hline VARIABLES & Model (1) & Model (2) & Model (3) & Model (4) & Model (5) & Model (6) & Model (7) \\
\hline & $(0.005)$ & $(0.005)$ & $(0.006)$ & $(0.005)$ & $(0.006)$ & $(0.006)$ & $(0.006)$ \\
\hline EMU & $\begin{array}{c}-0.174 * * * \\
(0.053)\end{array}$ & $\begin{array}{c}-0.149 * * * \\
(0.057)\end{array}$ & $\begin{array}{l}-0.111^{*} \\
(0.061)\end{array}$ & $\begin{array}{l}-0.104^{*} \\
(0.056)\end{array}$ & $\begin{array}{c}-0.188 * * * \\
(0.059)\end{array}$ & $\begin{array}{c}-0.166 * * * \\
(0.059)\end{array}$ & $\begin{array}{c}-0.142 * * * \\
(0.051)\end{array}$ \\
\hline Constant & $\begin{array}{c}-2.275^{* * * *} \\
(0.469)\end{array}$ & $\begin{array}{c}-2.080 * * * \\
(0.488)\end{array}$ & $\begin{array}{c}-1.942 * * * \\
(0.498)\end{array}$ & $\begin{array}{c}-2.278 * * * \\
(0.461)\end{array}$ & $\begin{array}{c}-2.330^{* * *} \\
(0.469)\end{array}$ & $\begin{array}{c}-2.371 * * * \\
(0.502)\end{array}$ & $\begin{array}{c}-3.127 * * * \\
(0.573)\end{array}$ \\
\hline Time Dummies & YES & YES & YES & YES & YES & YES & YES \\
\hline Hansen test & 0.188 & 0.340 & 0.238 & 0.523 & 0.143 & 0.144 & 0.383 \\
\hline $\mathrm{AR}(2)$ & 1.291 & 1.365 & 1.378 & 1.355 & 1.334 & 1.363 & 1.290 \\
\hline
\end{tabular}

Note: The table reports the dynamic panel regression results. The two-step GMM (Arellano and Bover, 1995) is used with Windmeijer corrected (robust) errors. We consider as exogenous the country-specific and time dummy variables and as endogenous the bank-specific variables. The instruments chosen for the lagged endogenous variables are two-to-six period lags. AR (2) stands for the p-value of the second order residual autocorrelation tests. Hansen test stands for the p-value of Hansen's J diagnostic test for instrument validity. The dependent variable is the capital buffer (BUFF) calculated as the regulatory capital (Tier 1 plus Tier 2 over Risk Weighted Assets) minus minimum capital requirement. L.BUFF is the lagged value of the dependent variable BUFF representing the dynamic nature of the model. EFF stands or the cost efficiency scores calculated using SFA methodology. ROE is the return on equity ratio, ROA the return on assets while NIM is the net interest margin. ALTMANZ presents Altman's Z-Score and is a measure of bank likelihood for default. NPL stands for the ratio of non-performing loan over total loans, OBS stands for the Off-Balance-Sheet items measured as the ratio of Off-BalanceSheet items over total liabilities. RWA stands for the bank risk exposure and is calculated as the ratio of risk-weighted assets over total assets, DISCLSR is a dummy taking the value 1 for listed banks and 0 unlisted and stands as a second measure of market discipline indicating information disclosure. SIZE is the log of total assets and measures the bank size while C5 stands for the five-firm concentration ratio of each country's banking industry. GDPGR stands for the GDP growth, EMU is a dummy taking the value 1 for banks in Eurozone and 0 otherwise and COM is a dummy taking the value 1 for commercial banks and 0 for saving banks.

***, ** and * indicate $1 \%, 5 \%$ and $10 \%$ significance levels respectively. 
Table 8: Results for dynamic panel threshold estimation with efficiency as threshold variable and buffer as dependent variable

\begin{tabular}{|c|c|c|c|}
\hline \multirow{3}{*}{$\begin{array}{l}\text { EFF } \\
95 \% \text { confidence interval }\end{array}$} & \multicolumn{2}{|l|}{0.729} & \\
\hline & \multicolumn{2}{|c|}{$(0.569-0.848)$} & \\
\hline & Coefficient & & S.E. \\
\hline \multicolumn{4}{|l|}{ Impact of Eff on Buffer } \\
\hline$\lambda 1$ & 1.652 & $* * *$ & 0.55 \\
\hline$\lambda 2$ & -1.20 & $* *$ & 0.462 \\
\hline \multicolumn{4}{|l|}{ Impact of covariates } \\
\hline Lag Buffer & 0.222 & $* * *$ & 0.035 \\
\hline Altman's z-score & 0.098 & $* * *$ & 0.018 \\
\hline Non-performing loans & 0.005 & & 0.004 \\
\hline Off-Balance-Sheet items & 0.034 & $*$ & 0.019 \\
\hline RWA & -0.619 & $* * *$ & 0.254 \\
\hline Size & 1.584 & $* * *$ & 0.308 \\
\hline $\mathrm{C} 5$ & -0.029 & & 0.230 \\
\hline GDP growth & -0.012 & $* * *$ & 0.004 \\
\hline Time Dummies & Yes & & \\
\hline$\delta$ & -0.222 & & 0.513 \\
\hline Observations & 1735 & & \\
\hline Low Regime & 468 & & \\
\hline High Regime & 1267 & & \\
\hline
\end{tabular}

Note: The table reports the estimation for dynamic panel threshold model. The threshold value of efficiency variable for banks ranges between 0.569 and 0.848 . We denote bank capital buffer (BUFF) as the dependent variable while as the threshold variable we impose bank cost efficiency (EFF) and as the regime dependent variable bank size. The model accounts for regime dependent intercepts $(\delta)$. In this model, $\mathrm{m}_{\mathrm{it}}$, includes bank-specific and country explanatory variables. As regards the bank-specific variables, we use: lagged capital buffer (Lag Buffer), Altman's Z-Score, non-performing loans, off-balance-items, RWA and size. As country variables, we employ: GDP growth rate and concentration ratio (C5). Finally, we include time dummies. $* * *, * *$ and $*$ indicate $1 \%, 5 \%$ and $10 \%$ significance levels respectively.

Table 9: Dynamic Threshold Analysis: classification of banks into low and high regimes based on threshold value of cost efficiency

\begin{tabular}{|c|c|c|c|c|c|c|c|c|c|}
\hline \multicolumn{10}{|c|}{ Threshold: Efficiency } \\
\hline & 2005 & 2006 & 2007 & 2008 & 2009 & 2010 & 2011 & 2012 & 2013 \\
\hline Low Regime & $10 \%$ & $12 \%$ & $18 \%$ & $35 \%$ & $25 \%$ & $20 \%$ & $24 \%$ & $34 \%$ & $34 \%$ \\
\hline High Regime & $90 \%$ & $88 \%$ & $82 \%$ & $65 \%$ & $75 \%$ & $80 \%$ & $76 \%$ & $66 \%$ & $66 \%$ \\
\hline
\end{tabular}

Note: The table shows the classification of banks based on the efficiency threshold value that we obtained following Kremer, Bick and Nautz (2013). 
Table 10: Results for dynamic panel threshold estimation with buffer as threshold variable and efficiency as dependent variable

\begin{tabular}{lcc}
\hline BUFF & 13.594 & \\
$95 \%$ confidence interval & $(9.458-13.855)$ & \\
\hline \multicolumn{1}{l}{ Coefficient } \\
\hline Impact of Buffer on Eff & & S.E. \\
\hline$\lambda 1$ & 0.008 & 0.005 \\
$\lambda 2$ & $0.018 * *$ & 0.008 \\
\hline Impact of covariates & & \\
\hline Lag Efficiency & 0.004 & 0.003 \\
Altman's Z-Score & $-0.006 \quad * * *$ & 0.002 \\
Non-performing loans & -0.0006 & 0.0004 \\
Off-Balance-Sheet items & -0.004 & 0.004 \\
RWA & $-0.090 \quad * * *$ & 0.029 \\
Size & $-0.196 \quad * * *$ & 0.037 \\
C5 & $0.120 * *$ & 0.071 \\
GDP growth & $0.001 \quad * * *$ & 0.0005 \\
Time Dummies & Yes & \\
$\Delta$ & 0.122 & 0.104 \\
\hline Observations & 1735 & \\
Low Regime & 1273 & \\
High Regime & 462 & \\
\hline Note: The able reports the & & \\
\hline
\end{tabular}

Note: The table reports the estimation for dynamic panel threshold model. The threshold value of buffer variable for banks ranges between 9.822 and 13.754 . We denote bank efficiency (EFF) as the dependent variable while as the threshold variable we impose the bank capital buffer (BUFF) and as the regime dependent variable bank size. The model accounts for regime dependent intercepts $(\delta)$. In this model, $m_{i t}$ includes bank-specific and country explanatory variables. As regards the bank-specific variables, we use: Lagged efficiency (Lag Efficiency), Altman's Z-Score, non-performing loans, off-balance-items, RWA and size. As country variables, we employ: GDP growth rate and concentration ratio (C5). Finally, we include time dummies. $* * *, * *$ and $*$ indicate $1 \%, 5 \%$ and $10 \%$ significance levels respectively.

Table 11: Dynamic Threshold Analysis: classification of banks into low and high regimes based on threshold value of buffer

\begin{tabular}{|c|c|c|c|c|c|c|c|c|c|}
\hline \multicolumn{10}{|c|}{ Threshold: Buffer } \\
\hline & 2005 & 2006 & 2007 & 2008 & 2009 & 2010 & 2011 & 2012 & 2013 \\
\hline Low Regime & $69 \%$ & $73 \%$ & $79 \%$ & $77 \%$ & $72 \%$ & $71 \%$ & $74 \%$ & $72 \%$ & $72 \%$ \\
\hline High Regime & $31 \%$ & $27 \%$ & $21 \%$ & $23 \%$ & $28 \%$ & $29 \%$ & $26 \%$ & $28 \%$ & $28 \%$ \\
\hline
\end{tabular}

Note: The table shows the classification of banks based on the buffer threshold value that we obtained following Kremer, Bick and Nautz (2013). 
Table 12: Results for dynamic panel threshold estimation with Z-Score as threshold variable and Buffer as dependent variable

\begin{tabular}{|c|c|c|c|}
\hline Altman's Z-Score & \multicolumn{2}{|l|}{7.382} & \\
\hline $95 \%$ confidence interval & \multicolumn{2}{|c|}{$(6.038-7.633)$} & \\
\hline & \multicolumn{2}{|l|}{ Coefficient } & S.E. \\
\hline \multicolumn{4}{|l|}{ Impact of Z-Score on Buffer } \\
\hline$\lambda 1$ & 0.228 & $* * *$ & 0.023 \\
\hline$\lambda 2$ & 0.011 & & 0.008 \\
\hline \multicolumn{4}{|l|}{ Impact of covariates } \\
\hline Lag Buffer & 0.197 & $* * *$ & 0.029 \\
\hline Efficiency & 1.009 & $* * *$ & 0.233 \\
\hline Non-performing loans & 0.004 & $* *$ & 0.002 \\
\hline Off-Balance-Sheet items & 0.016 & & 0.020 \\
\hline RWA & -0.823 & $* * *$ & 0.193 \\
\hline Size & 1.543 & $* * *$ & 0.219 \\
\hline $\mathrm{C} 5$ & -0.320 & & 0.842 \\
\hline GDP growth & -0.013 & $* * *$ & 0.003 \\
\hline Time Dummies & YES & & \\
\hline$\Delta$ & -1.584 & $* * *$ & 0.156 \\
\hline Observations & 1735 & & \\
\hline Low Regime & 1300 & & \\
\hline High Regime & 435 & & \\
\hline
\end{tabular}

Note: The table reports the estimation for dynamic panel threshold model. The threshold value of Altman's Z-Score variable for banks ranges between 6.038 and 7.610. We denote bank capital buffer (BUFF) as the dependent variable while as the threshold variable we impose Altman's Z-Score and as the regime dependent variable bank size. The model accounts for regime dependent intercepts $(\delta)$. In this model, $\mathrm{m}_{\mathrm{it}}$, includes bank-specific and country explanatory variables. As regards the bank-specific variables, we use: lagged capital buffer (Lag Buffer), Efficiency, non-performing loans, off-balance-items, RWA and size. As country variables, we employ: GDP growth rate and concentration ratio (C5). Finally, we include time dummies. $* * *, * *$ and $*$ indicate $1 \%, 5 \%$ and $10 \%$ significance levels respectively.

Table 13: Dynamic Threshold Analysis: classification of banks into low and high regimes based on threshold value of Z-Score

\begin{tabular}{|c|c|c|c|c|c|c|c|c|c|}
\hline \multicolumn{10}{|c|}{ Threshold: Altman's Z-Score } \\
\hline & 2005 & 2006 & 2007 & 2008 & 2009 & 2010 & 2011 & 2012 & 2013 \\
\hline Low Regime & $76 \%$ & $84 \%$ & $82 \%$ & $85 \%$ & $74 \%$ & $73 \%$ & $72 \%$ & $71 \%$ & $73 \%$ \\
\hline High Regime & $24 \%$ & $16 \%$ & $18 \%$ & $15 \%$ & $26 \%$ & $27 \%$ & $28 \%$ & $29 \%$ & $27 \%$ \\
\hline
\end{tabular}

Note: The table shows the classification of banks based on the Z-Score threshold value that we obtained following Kremer, Bick and Nautz (2013). 
Table 14: Results for dynamic panel threshold estimation with Buffer as threshold variable and Altman's Z-Score as dependent variable

\begin{tabular}{|c|c|c|c|}
\hline \multirow{3}{*}{$\begin{array}{l}\text { BUFF } \\
95 \% \text { confidence interval }\end{array}$} & \multicolumn{3}{|l|}{9.244} \\
\hline & \multicolumn{3}{|l|}{$(9.167-13.492)$} \\
\hline & Coefficient & & S.E. \\
\hline \multicolumn{4}{|l|}{ Impact of Buffer on Z-Score } \\
\hline$\lambda 1$ & 0.760 & $*$ & 0.407 \\
\hline$\lambda 2$ & 1.184 & $* * *$ & 0.269 \\
\hline \multicolumn{4}{|l|}{ Impact of covariates } \\
\hline Lag Altman's Z-Score & 0.036 & & 0.024 \\
\hline Efficiency & 2.682 & & 2.320 \\
\hline Non-performing loans & 0.020 & & 0.022 \\
\hline Off-Balance-Sheet items & 0.118 & & 0.234 \\
\hline RWA & -8.470 & $* * *$ & 2.50 \\
\hline Size & 4.672 & & 3.643 \\
\hline $\mathrm{C} 5$ & 0.038 & & 1.154 \\
\hline GDP growth & 0.042 & & 0.027 \\
\hline Time Dummies & Yes & & \\
\hline$\delta$ & 5.023 & & 4.022 \\
\hline Observations & 1735 & & \\
\hline Low Regime & 90 & & \\
\hline High Regime & 1645 & & \\
\hline \multicolumn{4}{|c|}{$\begin{array}{l}\text { Note: The table reports the estimation for dynamic panel threshold model. The } \\
\text { threshold value of BUFF variable for banks ranges between } 9.167 \text { and } 13.492 \text {. } \\
\text { We denote Altman's Z-Score as the dependent variable while as the threshold } \\
\text { variable we impose capital buffer (BUFF) and as the regime dependent variable } \\
\text { bank size. The model accounts for regime dependent intercepts }(\delta) \text {. In this model, } \\
\mathrm{m}_{\text {it, includes bank-specific and country explanatory variables. As regards the }} \\
\text { bank-specific variables, we use: lagged Altman's Z-Score, Efficiency, non- } \\
\text { performing loans, off-balance-items, RWA and size. As country variables, we } \\
\text { employ: GDP growth rate and concentration ratio (C5). Finally, we include time } \\
\text { dummies. ***,** and * indicate } 1 \%, 5 \% \text { and } 10 \% \text { significance levels respectively. }\end{array}$} \\
\hline
\end{tabular}

Table 15: Dynamic Threshold Analysis: classification of banks into low and high regimes based on threshold value of buffer

\begin{tabular}{lccccccccc}
\hline Threshold: Buffer & & & & & & & & \\
\hline & 2005 & 2006 & 2007 & 2008 & 2009 & 2010 & 2011 & 2012 & 2013 \\
\hline Low Regime & $10 \%$ & $7 \%$ & $15 \%$ & $16 \%$ & $15 \%$ & $15 \%$ & $17 \%$ & $15 \%$ & $13 \%$ \\
High Regime & $90 \%$ & $93 \%$ & $85 \%$ & $84 \%$ & $85 \%$ & $85 \%$ & $83 \%$ & $85 \%$ & $87 \%$ \\
\hline
\end{tabular}

Note: The table shows the classification of banks based on the buffer threshold value that we obtained following Kremer, Bick and Nautz (2013). 
Figure 4: Impulse Response Functions for bank capital buffer, Altman's Z-Score and efficiency

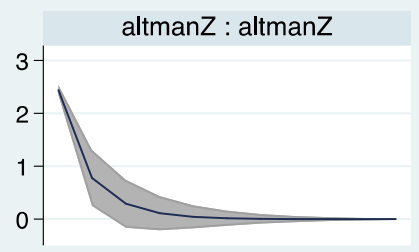

eff : altmanZ

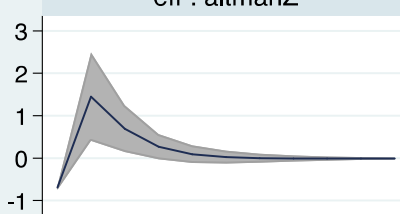

bff : altmanZ

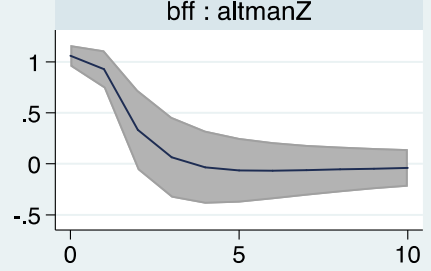

10

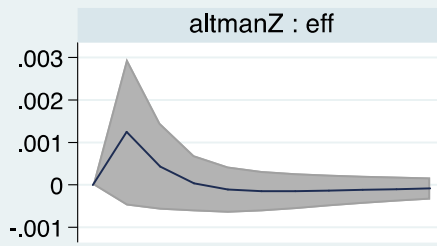

eff : eff

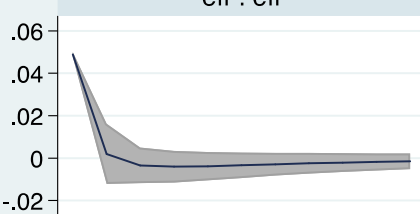

bff : eff

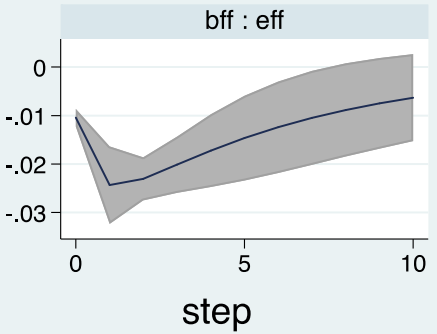

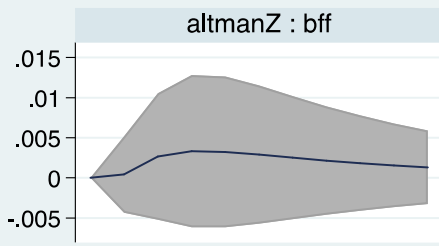

eff : bff

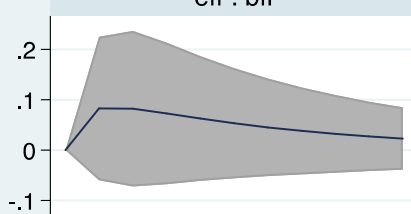

bff : bff

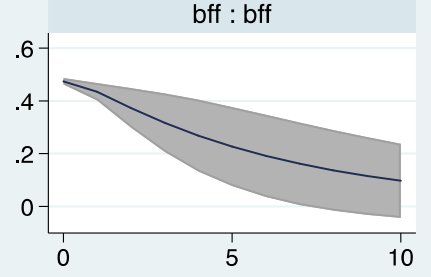

$95 \% \mathrm{Cl}$

Orthogonalized IRF

impulse : response

Note: The figure presents Impulse Response Functions for: BFF which stands for the bank capital buffer, EFF which is bank efficiency and ALTMANZ is the Altman's Z-Scores. Finally, $s$ is the number of time periods ahead. Dashed lines are 5\% S.E. on each side generated by Monte Carlo with 500 replications.

Table 16: Variance Decompositions for bank capital buffer, Altman's ZScore and efficiency

\begin{tabular}{|r|cccc|}
\hline Response variable & \multicolumn{4}{|c|}{ Impulse variables } \\
\hline & $\mathrm{s}$ & $\mathrm{BFF}$ & $\mathrm{EFF}$ & ALTMANZ \\
\hline BFF & 10 & 0.96561 & 0.03433 & 0.0000596 \\
$\mathrm{EFF}$ & 10 & 0.508 & 0.49163 & 0.0003685 \\
ALTMANZ & 10 & 0.17755 & 0.2633 & 0.5591566 \\
\hline
\end{tabular}

Note: The table presents the Variance Decompositions for: BFF which stands for the bank capital buffer, EFF which is bank efficiency and ALTMANZ presents the Altman's ZScores. Finally, s is the number of time periods ahead (years). 